\title{
Is there a gender gap in equity-based crowdfunding?
}

\author{
Jörg Prokop (iD) Dandan Wang
}

Accepted: 1 October 2021 / Published online: 19 November 2021

(C) The Author(s) 2021, corrected publication 2022
Plain English Summary Equity crowdfunding enables female entrepreneurs to narrow the "gender gap" in venture financing. In this paper, we investigate whether the entrepreneurs' gender affects how successful they are in attracting capital in the German equity crowdfunding market. Our results indicate that the gender of a firm's managing director does not affect the funding outcome in initial equity crowdfunding campaigns. In seasoned equity crowdfunding offerings, though, we identify a gender gap in the sense that ventures with female managing directors are significantly less successful in raising capital from crowd investors than ventures solely led by men. However, this gender gap in seasoned offerings narrows for bolder campaign pitches. Hence, setting a higher funding threshold seems to be a simple and straightforward strategy for female entrepreneurs to increase the odds of reaching their funding targets.

Keywords Crowdinvesting - Entrepreneur - Equitybased crowdfunding $\cdot$ Female entrepreneur $\cdot$ Gender gap $\cdot$ Venture financing

\section{JEL classification $\quad \mathrm{G} 32 \cdot \mathrm{J} 16 \cdot \mathrm{O} 16$}

\section{Introduction}

The emergence of equity crowdfunding has brought about a financing channel that may facilitate entrepreneurs' access to external funding and allow new, 
more heterogeneous groups of investors to invest in young ventures. In this regard, equity crowdfunding is considered a powerful tool that may democratise entrepreneurial finance (Cumming et al., 2021) by giving groups of entrepreneurs who historically have been underrepresented in traditional capital markets a better chance to attract funding (Mollick \& Robb, 2016).

The existing evidence on whether crowdfunding meets these expectations and reduces economic frictions associated with, for instance, the age, size, or ethnicity of the founder team, is mixed (Coakley et al., 2021a; Cumming et al., 2021; Duarte et al., 2012; Greenberg \& Mollick, 2018; Pope \& Sydnor, 2011; Younkin \& Kuppuswamy, 2018). In this paper, we contribute to this field of research by investigating whether equity crowdfunding is subject to gender-specific constraints in accessing external capital. The so-called "gender gap" is the pervasive phenomenon that, even after controlling for confounding factors, female entrepreneurs raise significantly smaller amounts of capital for their ventures than their male peers (Buttner \& Rosen, 1988; Orser et al., 2006; Stein et al., 2013). Such gender-related differences seem to exist in both traditional debt and equity financing (Alesina et al., 2013; Fay \& Williams, 1993; Orser et al., 2006; Riding \& Swift, 1990), as well as in venture capital and business angel financing (Becker-Blease \& Sohl, 2007; Brush et al., 2004; Greene et al., 2001; Marlow \& Patton, 2005). However, recent studies lend some empirical support to the notion that, compared to their male peers, female entrepreneurs have at least an equal chance of successfully acquiring capital through donation-, reward-, and loan-based crowdfunding. Hence, these forms of crowdfunding seem to alleviate gender constraints related to traditional financing channels. Potential reasons for this effect include lower information asymmetries due to more direct (online) communication between entrepreneurs and potential funders, lower barriers to entry for potential investors, and a more balanced investor base, especially with respect to the investors' gender (see, for instance, Barasinska \& Schäfer, 2014; Duarte et al., 2012; Gafni et al., 2021; Mollick, 2013; Pope \& Sydnor, 2011).

However, whether these findings also hold with respect to equity crowdfunding is an open issue since equity crowdfunding is inherently different from other forms of crowdfunding (Block et al., 2018; Cholakova \& Clarysse, 2015; Courtney et al., 2017; Cumming et al., 2021; Geiger \& Oranburg, 2018). In terms of its idea and purpose, it is more akin to traditional public and private equity financing (Cummings et al., 2020). Therefore, investors in equity crowdfunding campaigns may exhibit preferences and behavioural patterns similar to those of investors using traditional financing channels and pledge more money to male-led ventures (Geiger \& Oranburg, 2018; Vismara et al., 2017). Nevertheless, recent studies document a certain diversity in financial literacy among investors in equity crowdfunding. In contrast to their professional peers who follow what is sometimes termed a market logic, private and less sophisticated investors tend to follow a community logic (Cumming et al., 2021). Hence, their behaviour may differ substantially from that of investors in other forms of venture financing and be less biased against female entrepreneurs (Cumming et al., 2021; Rossi et al., 2021).

In this context, our study seeks to answer three questions. First, we investigate whether there is, in fact, a gender gap in equity crowdfunding with respect to new ventures. Second, we investigate whether a gender gap is present in seasoned equity crowdfunding campaigns - that is, in ventures that already successfully completed at least one earlier round of crowdfunding. Since funding targets are typically higher for seasoned campaigns, investors attracted by these campaigns might differ from investors participating in initial offerings. In particular, in seasoned campaigns we expect the investor base to tilt towards more profit-oriented and less risk averse investors whose investment decisions are less motivated by the motive of being part of a community of investors. Therefore, pre-existing gender stereotypes should have a stronger effect on seasoned offerings than on initial offerings. Third, conditional on the identification of a gender gap in initial and/or seasoned crowdfunding campaigns, we seek to shed light on how female entrepreneurs might adjust their pitching behaviour to counteract potential discrimination by crowd investors. In line with Lee and Huang (2018) and Kanze et al. (2018), we expect more competitive, promotion-focussed pitches by female 
entrepreneurs to lead to better funding outcome since they signal higher levels of role congruity as well as more favourable risk-adjusted return prospects.

To answer the first research question, we analyse the funding patterns of a sample of 231 first-time equity crowdfunding campaigns promoted on 15 German crowdfunding platforms with respect to the gender dimension. We thereby focus on situations in which female founders hold a prominent position in the venture's team of managing directors and investigate whether this plays a role in explaining how successful the venture is in attracting external funding. To answer the second and the third research questions, we investigate the effect of the managing directors' gender on funding success by conducting weighted regressions on a propensity score-matched sample of 170 initial and seasoned equity crowdfunding campaigns.

Our results show that ventures with more female founders in the team of managing directors do not underperform their peers in initial offerings, which aligns with previous findings by Cumming et al. (2021) and Rossi et al. (2021). Moreover, we identify a gender disparity in seasoned offerings, as ventures with more females in the team of managing directors are significantly less successful in raising equity capital from crowd investors, even after controlling for other entrepreneur-specific or venture-specific characteristics. Finally, we provide evidence that female entrepreneurs may improve funding success in initial offerings and narrow the gender gap in seasoned offerings by increasing the funding threshold, that is, by rendering their campaign pitches more promotionfocussed. Overall, our results are, thus, relevant for both female entrepreneurs and crowd investors, and they may also be of use to policymakers and financial intermediaries (such as crowdfunding platforms) aiming to facilitate female entrepreneurs' access to capital.

The rest of this paper is structured as follows. In Section 2, we provide a brief overview of the existing literature on gender-specific differences in crowdfunding. In Section 3, we describe the data and outline our research methodology. In Section 4, we discuss the results of our empirical analysis. In Section 5, we outline the implications as well as the limitations of our study and discuss some potential directions for future research.

\section{Hypotheses}

2.1 Gender gaps in initial and seasoned equity crowdfunding campaigns

There is a broad consensus in the literature that female entrepreneurs face substantial constraints in accessing external funding in traditional financial markets (Alesina et al., 2013; Aristei \& Gallo, 2016; Coleman \& Robb, 2009; Orser et al., 2006). Likewise, previous research shows that gender-related differences occur with respect to venture capital and business angel financing (Becker-Blease \& Sohl, 2007; Guzman \& Kacperczyk, 2019; Kanze et al., 2018). Regarding donation-, reward-, and loanbased crowdfunding, extant literature offers some empirical evidence as to female entrepreneurs having at least an equal chance of successfully acquiring capital (see, for instance, Barasinska \& Schäfer, 2014; Duarte et al., 2012; Gafni et al., 2021; Greenberg \& Mollick, 2017; Mollick, 2013; Pope \& Sydnor, 2011; Ravina, 2019). In this regard, these forms of crowdfunding seem to contribute to the democratisation of entrepreneurs' access to external capital with respect to the gender dimension.

Empirical evidence on a potential gender gap in equity crowdfunding is scarce and the few existing studies' findings are mixed. Investigating 58 equity offerings on the UK platform Seedrs in the period October 2015-March 2016, Vismara et al. (2017) obtain ambiguous results with respect to the effects of female CEOs, and of the share of females in top management teams, on funding outcome. While the former seems to have a positive bearing on campaign success, the latter rather seems to hinder it. Geiger and Oranburg (2018) analyse 243 equity crowdfunding campaigns in the US market through mid-March 2018. They find a significantly lower amount of capital raised by female entrepreneurs than by their male peers. Therefore, they conclude that equity crowdfunding might not have a democratising effect, at least not with respect to the gender dimension. In line with this view, recent studies by Greenberg and Mollick (2017), Mohammadi and Shafi (2018), and Vismara et al. (2017) investigate gender-related dissimilarities in investment behaviour. They provide evidence of a male-dominated investor base and of gender-related homophily 
in equity crowdfunding which also suggests that equity crowdfunding may be subject to gender-specific bias.

Cumming et al. (2021), however, come to a different conclusion. They investigate 167 equity offerings in the UK platform Crowdcube and 99 initial public offerings on London's Alternative Investment Market. They find that female leadership, as well as female presence in the top management team, does not affect the success of a crowdfunding campaign. Similarly, based on a dataset of 3576 initial offerings in the UK and US markets, Rossi et al. (2021) report that female founders are more likely to set a lower funding target in equity crowdfunding, while not raising significantly more capital than their counterparts. They posit that, overall, female founders do not have higher chances of reaching their target and they document a preference of female founders for platforms that have created a more inclusive environment for women and minorities.

In sum, extant empirical evidence does not draw a clear picture of whether equity crowdfunding mitigates gender-specific differences in entrepreneurial finance. The reason for this apparent difference between equity crowdfunding and the other forms of crowdfunding may be that the former inherently differs from latter in several ways. For instance, while funders in reward-based crowdfunding campaigns tend to be more socially inclined, and driven mostly by intrinsic factors, investors in equity crowdfunding are primarily motivated extrinsically by the prospect of generating financial returns (Cholakova \& Clarysse, 2015; Courtney et al., 2017; Geiger \& Oranburg, 2018; Kuppuswamy \& Bayus, 2018). Moreover, compared to loan-based crowdfunding, equity crowd investors' investment horizon is typically longer (Block et al., 2018; Cholakova \& Clarysse, 2015), and the prospect of upside participation in the venture's long-term development comes into play. Thus, investors engaging in equity crowdfunding are likely to exhibit patterns of investment behaviour that are more similar to those of investors in more traditional public and private equity offerings. ${ }^{1}$ Given what we know about the effects of pre-existing gender stereotypes on investment decisions, this suggests that they

\footnotetext{
$\overline{1}$ Cummings et al. (2020, p. 908) position equity crowdfunding "at the intersection of public and private equity financing".
}

might favour ventures led by male entrepreneurs as well (Johnson et al., 2018; Lee \& Huang, 2018).

However, two factors call for a more differentiated view on potential gender discrimination in equity crowdfunding. First, compared to participants in traditional capital markets, the group of equity crowd investors is typically more diverse in terms of investor sophistication and experience, with a large share of amateur investors following a community logic instead of a market logic (Cumming et al., 2021). This makes the actual investment behaviour of equity crowd investors less predictable. Second, despite a quickly growing number of follow-on (or seasoned) campaigns (Hornuf \& Schwienbacher, 2018), extant research largely focuses on first-time equity offerings and does not account for potential differences in investor base and investor behaviour between the two types of campaigns. ${ }^{2}$ However, in the case of seasoned offerings, the entrepreneurs have already conducted at least one earlier round of equity crowdfunding successfully. Hence, they tend to be more experienced in promoting their venture, and may have built up reputation capital with existing investors. Moreover, a successful prior funding round sends a positive signal to prospective investors (Kleinert et al., 2020) and, thus, mitigates information asymmetries (Coakley et al., 2021b; Signori \& Vismara, 2018).

While the aforementioned factors should have a mitigating effect on investors' potential gender stereotypes, there are a few reasons why gender-specific differences in seasoned offerings may still affect funding success. First, seasoned offerings typically seek higher target amounts of capital. Consequently, they may attract more profit-oriented investors whose risk preferences and intentions differ significantly from those of the average investor in initial crowdfunding campaigns. Moreover, crowd investors might perceive seasoned offerings as signals of potential opportunistic behaviour (Coakley et al., 2021b) or moral hazard. In both cases, the investor base is likely to tilt towards

\footnotetext{
2 Among the few empirical studies on seasoned offerings are Cumming et al. (2021), Coakley et al. (2021a), Hornuf et al. (2018), and Kleinert et al. (2020) who investigate the determinants of launching, or successfully completing, seasoned campaigns. Moreover, Vanacker et al. (2019) and Signori and Vismara (2018) study the performance of ventures after their initial crowdfunding campaign.
} 
more profit-oriented and less risk averse investors whose investment decisions are less motivated by the motive of being part of a community of investors. Consequently, we expect seasoned offerings to be more affected by pre-existing gender stereotypes than initial offerings.

Against this background, we test the following two hypotheses:

H1: Ventures with and ventures without female managing directors are equally successful in raising capital in initial equity crowdfunding campaigns.

$\mathrm{H} 2$ : Ventures with female managing directors are less successful in raising capital in seasoned equity crowdfunding campaigns.

\subsection{Mitigating gender gaps in equity crowdfunding}

In case that equity crowdfunding is not entirely free from gender-specific bias, the question arises whether there is a recommended course of action for female entrepreneurs to mitigate respective effects. To answer this question, we draw on recent research trying to explain the gender gap in venture capital financing. In this context, Guzman and Kacperczyk (2019) find that around two-thirds of the observable gender gap can be explained by women being less likely to start ventures that signal growth potential to external investors, while the remaining one-third likely reflecting gender-specific discrimination by venture capitalists. In addition, Alsos and Ljunggren (2017) and Eddleston et al. (2016) show that venture capitalists' perception and evaluation of signals sent by the entrepreneur may be contingent on the entrepreneur's gender. In particular, Eddleston et al. (2016) find that women are disadvantaged in terms of rewards to positive entrepreneurial signals (like the number of employees and past performance) and that certain negative signals of venture viability (such as the newness of the business) hamper female entrepreneurs' success but do not seem to affect their male counterparts.

These findings suggest that gender role incongruity might be a potential driver of the gender gap in entrepreneurial finance. If potential male and female investors perceive the wish to start a business as more "masculine" (Gupta et al., 2009; Marlow \& Patton, 2005), then their stereotypical perception of female founders does not align with their mental model of the "typical" entrepreneur (Lee \& Huang, 2018). Consequently, they are likely to evaluate ventures started by male entrepreneurs more favourably. Recent research by Kanze et al. (2018), who attribute the gender gap in venture financing to self-regulatory effects with respect to the entrepreneur-investor interaction, supports this notion. They find that investors tend to ask female entrepreneur prevention-focussed questions while their male peers are being asked promotion-focussed questions. Moreover, entrepreneurs tend to respond to these questions with matching regulatory focus, thereby reinforcing preexisting stereotypes. Kanze et al. (2018) identify this effect as one of the main drivers of differences in funding amounts between ventures founded by women and ventures founded by men. Thus, to overcome potential gender biases, they advise female entrepreneurs to reply to prevention-focussed questions asked by investors with promotion-focussed answers. Applying the same logic to equity crowdfunding, we hypothesise that female entrepreneurs can signal a higher level of role congruity to rent-seeking crowd investors, and thereby improve their funding outcomes, by rendering their campaign pitch more promotion-focussed. A simple and straightforward way to implement this strategy would be for female founders to set a higher funding threshold, that is, a higher minimum amount of capital that has to be raised for the campaign to be considered successful. Hence, we propose the following third hypothesis:

H3: Female entrepreneurs can narrow potential gender gaps in equity crowdfunding by setting higher funding thresholds.

\section{Research design and methodology}

\subsection{Research design}

We conduct a three-step analysis of gender-related differences in equity crowdfunding. Examining venture promotions on equity crowdfunding platforms, we first specify four categories of characteristics that might play a role in explaining the attractiveness of fundraising ventures, and hence the funding outcomes. The first category consists of selected features of the funding campaign, including on which 
platform the project is posted, and whether the venture has already completed previous equity crowdfunding rounds. The second category is directly related to venture promotion. It focusses on the project description posted on the campaign website and consists of factors that might catch the eye of crowd investors and keep their interest, such as the length of any videos and the number of photos available. The third category consists of entrepreneurial characteristics, and the fourth category contains venture-specific characteristics. The respective variables are discussed in detail in Section 3.2.

In the second step of our analysis, we conduct multiple regression analyses to gauge the influence of the aforementioned variables on funding outcomes, focussing on the entrepreneur-related variables. Since most of the equity crowdfunding platforms in our sample are profit-oriented enterprises, potential sample selection bias is a problem we have to account for in our analysis. In order to hide poor performance and establish or maintain a good reputation among entrepreneurs and investors, equity crowdfunding platforms might be selective regarding the information they display on their websites about past funding campaigns. Some provide more information about successful campaigns and less about those that were unsuccessful. Some even omit unsuccessful campaigns from their websites entirely. In the context of our analysis, this might lead to the oversampling of successful campaigns, implying an overestimation of the campaigns' performance and bias the empirical analysis of the determinants of funding outcomes. To control for this potential sample selection bias, we include both successful and failed equity crowdfunding offerings in our sample. Further, we conduct respective web searches to harvest data on unsuccessful funding campaigns in particular. Furthermore, we employ inverse probability weighting to address the oversampling problem using the proportion of campaigns that have reached their funding target from the raw dataset (cf. Section 3.3) as the population's success rate. As a robustness check, we conduct further regression analyses omitting oversampling weights.

In the third step of our analysis, we examine whether the results from the second step also hold for seasoned equity crowdfunding offerings, especially whether ventures with more females in their team of managing directors are disadvantaged when launching seasoned campaigns. Since we cannot conduct a regression analysis on seasoned offerings only due to small sample size, we conduct the analysis on the full sample including both initial and seasoned offerings. At this point, it is worth noting that different characteristics of the entrepreneurs and ventures might influence both the funding outcome and the likelihood of whether such ventures might have pursued equity-based crowdfunding earlier. With the existence of such confounding variables, there is a risk that the regression model suffers from an endogeneity problem. Moreover, ventures that have already completed equity crowdfunding campaigns before might be more likely to pursue a follow-up equity crowdfunding campaign, indicating a potential self-selection bias. To remedy these concerns, we refrain from simply distinguishing the effects for initial and seasoned campaigns based on interaction terms. Instead, we use propensity score matching with the launch of a seasoned offering as the treatment variable to create a sample in which the confounding variables-entrepreneur and venture characteristics-are balanced among the treatment and control groups. ${ }^{3}$ Conditional on the confounding variables, we estimate the probability of having launched a seasoned equity crowdfunding campaign (the propensity score) for each observation. Then, we match and weigh the observations based on their propensity scores. As a result, company- and managing director-related characteristics should not significantly deviate across matched samples. To ensure good comparability of the characteristics between the treatment and control groups, we impose the common support condition ${ }^{4}$. We discard treated observations with propensity scores larger than the maximum score or smaller than the minimum score in the control group. Based on the matched sample, we then conduct multiple regression analyses to examine the influence of the interaction between gender and seasoned offering on funding

\footnotetext{
${ }^{3}$ For other studies applying the propensity score matching approach in a crowdfunding context, see, for instance, Coakley et al. (2021a) and Cumming et al. (2020).

4 The common support condition is one of the key assumptions underlying propensity score matching. It requires that observations with the same characteristics have a positive probability of being both treated and untreated (Caliendo \& Kopeinig, 2008, p. 4). That is, matched observations are comparable in the sense that the propensity score of an observation in one group lies between the minimum and the maximum propensity scores of the observations in the other group.
} 
outcomes. Throughout, the data again incorporate the oversampling weights with respect to successful campaigns from step two of the analysis.

\subsection{Variables and model specification}

Our investigation of gender-related disparities in equity crowdfunding is based on publicly available campaign data published by crowdfunding platforms. We infer the entrepreneurs' gender from their first names as well as from other available information (such as photographs), and our main variable of interest is each venture's ratio of female managing directors relative to all members of the board of directors. In addition, for each campaign we hand-collected from the platforms' websites further campaignrelated, entrepreneur-related, promotion-related, and venture-related information as detailed below. ${ }^{5}$

The first category of variables consists of factors related to the funding campaign. The funding outcome is the dependent variable and is measured as funding success, a dummy variable equal to 1 if the raised amount reaches the target and 0 otherwise. As alternative measures of funding outcome, we use the natural logarithm of the funding amount, as well as the number of investors.

Ln(funding threshold) is the natural logarithm of the pre-determined funding threshold, that is, of the minimum amount of capital that has to be raised for the campaign to be considered successful under the All-or-Nothing financing model. ${ }^{6}$ If the threshold is not reached by the end of the campaign, the invested capital will be returned to the crowd investors. The effect of this threshold on funding outcome is controversial. Typically, whether or not a campaign has reached its funding threshold will be clearly signalled to the crowd investors on the platform's website. Often, the venture will also actively post a respective notification. Therefore, on the one hand, a campaign with a relatively low funding threshold is, ceteris paribus, more likely to be successful, which induces a positive signal to current and potential investors and

\footnotetext{
5 Online Appendix A.1 provides an overview of the dependent and independent variables used in this study.

${ }^{6}$ Under the Keep-it-All financing model, this variable would include missing values. However, since no venture in our final sample applies the Keep-it-All financing model, this does not have an influence on our empirical analysis.
}

attracts further investments. ${ }^{7}$ On the other hand, however, crowd investors might as well interpret a relatively low funding threshold as a sign that the entrepreneurs lack confidence in the venture, which would likely reduce its attractiveness as an investment. The net impact of these two effects is unclear and will be assessed in our empirical analysis.

Our regression models incorporate the funding threshold instead of the funding target in order to control for the entrepreneurs' or founders' initial capital needs in light of the following considerations: First, it is difficult to deduce a causal link between the funding target and funding outcomes from their interactive relationship. During the campaign window, ventures have the option to raise their funding targets on the basis of the interim funding performance. The funding target might largely differ from the initial capital needs. Second, the funding target is supposed to have an influence on the decision taken about setting the funding threshold; the latter often being preset proportional to the former. This can be substantiated by the high pairwise correlation between them ( 0.53 based on the raw sample and 0.61 based on the final sample; significant at the $0.1 \%$ level). ${ }^{8}$ Third, similar to the funding limit, the funding target, either the initial or final one, may be partially settled by the motivation of ventures to withdraw from the costly information disclosure requirement. The German national securities law requires ventures to publish a capital investment prospectus when the total share selling price exceeds $€ 100,000$ or $€ 2.5$ million when they use tools such as profit-participating and subordinated loans as financing instruments. Therefore, we conjecture that the pre-determined funding threshold would signify the venture's initial capital needs to a certain degree. To investigate whether pitching a campaign in a more promotion-focussed way helps female entrepreneurs improve the funding outcome (H3), we incorporate an interaction term between the funding threshold and the gender variable in regression analyses. A higher funding threshold should signal a higher level of role congruity to rent-seeking investors, and thereby alleviate potential gender

\footnotetext{
$\overline{7}$ Block et al. (2018) find a positive association between campaign development and funding outcomes in the German equity crowdfunding market.

${ }^{8}$ See Online Appendix A.3 for details.
} 
biases in equity crowdfunding. Therefore, we expect the interaction term to be positively associated with the funding outcome.

Seasoned takes the value of 1 if the venture has already successfully pursued equity-based crowdfunding earlier. We expect the interaction term between this variable and the female ratio to have a significant association with the funding outcome variables for seasoned offerings (H2).

Whether the funding campaign's duration has been extended is also considered in the model. Its influence on the funding outcome, however, needs close examination. The venture has the option to renegotiate the campaign deadline with the platform and to extend it. In practise, this is often the case when the campaign is not as successful as expected and the venture requires more time to reach its preset funding threshold under the All-or-Nothing model or funding goal under the Keep-it-All model. However, an extension of the funding phase can also occur if the campaign process is more successful than anticipated. If the entrepreneur believes that the venture will reach the pre-determined funding threshold or funding goal more quickly than expected, they can either extend the campaign deadline or increase its funding goal (and funding limit if there is any) in order to achieve a better funding outcome.

The dummy variable platform big takes the value of 1 if the venture is promoted on one of the following platforms: Seedmatch, Companisto, Conda, Greenrocket, or Innovestment ${ }^{9}$. This variable hence serves as a proxy for platform-specific characteristics that are otherwise difficult to quantify. As crowdfunding platforms are profit-oriented and charge successfully financed ventures a fee (typically a certain percentage of the funds raised), they usually screen applications and select those with the greatest success potential. In addition, they may provide services, guidance, and advice to fundraisers. The big platforms, meaning the main players in the equity-based crowdfunding market, are likely to provide fund-raising ventures with more professional support to help them attract funding.

\footnotetext{
9 These platforms cover $72.26 \%$ of all the equity-based crowdfunding campaigns in the raw dataset and financed $79 \%$ of the successful campaigns in the raw dataset.
}

FI denotes the financing instruments employed by ventures. Four financing instruments are specified in the dataset: participation right, subordinated loan, profit-participating and subordinated loan, and silent partnership. Since June 2012, the public offerings of silent partnerships have been subject to the prospectus requirements once the threshold of $€ 100,000$ per year is exceeded, whereas profit-participating and subordinated loans remained not categorised as investments until 2015. It is particularly reasonable to presume that campaigns with profit-participating and subordinated loans are differentiated to a significant degree from those employing the other financing instruments in terms of the funding capacity and investor base and, thus, it is important to control the effects of these factors on the funding outcome. Hornuf and Schwienbacher (2018) provide evidence on the significant influence of profit-participating loans on the funding outcome in terms of crowd participation, the likelihood of campaign success, and the amount of capital raised. Following their results, we incorporate a dummy variable that takes a value of 1 for profit-participating loans and 0 if another instrument is employed.

The variable other bonus is a dummy variable. It takes the value of 1 when the venture provides bonuses besides interest payment and profit participation and 0 otherwise. It is supposed to have a positive association with the funding outcome.

The year in which the funding campaign ended is also considered in the model to account for structural changes in the regulations as well as the development of the German equity-based crowdfunding market.

The length of promotion videos (in minutes), the number of photos and images, and the number of letters and characters in the description (in thousands) are included in the second category. These factors are presumably most relevant to catch the eye of crowd investors and to peak their interest and hence contribute to the funding success. Similarly, Mollick (2014) uses the existence of a project pitch video as well as the existence of spelling errors in the project pitch description as proxies for the venture quality, while Crosetto and Regner (2014) identify the number of words, videos, and images as success determinants.

Five independent variables related to entrepreneurs are included in the third category: the female ratio, that is, the venture's ratio of female directors relative 
to all managing directors ${ }^{10}$, the average risk-taking propensity of the managing directors, a dummy variable indicating solo founders, the average age of the managing directors, and the educational level of the managing directors (i.e. whether they have a doctoral degree). Nelson (2003) investigates the persistence of the founder influence to find that investors react more strongly to the initial public offerings of firms with founders still involved. Further, previous studies have shown an association between the entrepreneurial characteristics and (new) venture performance in terms of longevity, financial strength, investment activity, and profitability. Ling et al. (2007) illustrate the influence of the founder CEOs' personal values (such as collectivism and novelty) on their new venture performance. Furthermore, the risk preferences of CEOs affect their corporate decisions, firm risk, and firm performance and should therefore have a bearing on the investment decisions made by crowd investors. However, empirical research has found the relationship between risk propensity and firm performance to be ambiguous. Tang et al. (2010) and Lechner and Gudmundsson (2014) identify a negative association, whereas Thapa (2015) states that risk propensity does not play a role in microenterprise performance.

The age and the educational background of managing directors signal entrepreneurial human capital. Younger managing directors tend to be more successful and have a higher innovation capability. Yet, there is also contradictory evidence that older managing directors are more likely to diversify operations with an aim to reduce firm risk (see, for instance, Serfling, 2014). Cumming et al. (2021) find that younger top management teams (TMTs) are more likely to launch successful equity crowdfunding campaigns and attract more crowd investors. Bates (1990) states that the founders' education level is a significant determinant of firm survival, while Hsu (2007) find that a doctoral degree holder in the founder team increases the probability of the firm raising venture capital funding ${ }^{11}$.

\footnotetext{
${ }^{10}$ Given that about $31.37 \%$ ventures in our final dataset have more than one managing director, we investigate the proportion of females in the team of managing directors rather than a dummy variable indicating the existence of females in the team.

11 We considered applying the MBA degree to measure the managing directors' human capital. However, a closer examination of our raw data revealed that holding an MBA degree
}

In the context of equity crowdfunding, Ahlers et al. (2015) show that signals indicating an educational background in business administration (MBA ownership) are associated with faster accumulation of crowd capital and higher numbers of investors.

In our analysis, we include a solo founder dummy, instead of the number of managing directors, along with the other managing director-related variables. In our view, the former variable better captures the broader social capital the venture has accumulated since its foundation. Social networks facilitate ventures' capability of acquiring information and resources necessary for survival and viability (see, for instance, Haleblian \& Finkelstein, 1993; Eisenhardt \& Schoonhoven, 1990). Especially start-ups and SMEs, the main players in the equity crowdfunding market tend to rely more on the inflow of external resources due to their lower levels of legitimacy and market recognition. As such, in accordance with the social network theory and the signalling theory, a larger founder team should therefore serve as a positive signal of venture quality and prospect. However, ventures with large founder teams might suffer from "social loafing", whereby individuals' performance can decrease when working in groups (Latane et al., 1979). The process loss theory developed by Steiner (1972) explains why individuals in larger teams perform worse than their peers. Mueller (2012) further develops this theory, specifying relational loss as an additional source of process loss. Therefore, the magnitude and the direction of the effects of the solo founder on a venture's crowdfunding performance depend on how the crowd perceives and weighs the positive and negative aspects of having a solo founder when making investment decisions. The existing literature provides controversial evidence with regard to the role of team size in funding performance. Cumming et al. (2021) document that smaller TMTs are more likely to choose equity crowdfunding offerings over IPOs but do not have a higher likelihood of success. They also provide (weak) evidence that

\section{Footnote 11 (continued)}

is a rare event among the managing directors in our sample. In the case of successful campaigns, $3.32 \%$ of managing directors hold an MBA, while no managing director holds an MBA in the subsample of unsuccessful campaigns in our dataset. In contrast, the ratios of doctoral degree holders for failed and successful campaigns are $3.61 \%$ and $12.25 \%$, respectively. 
smaller-sized TMTs attract more crowd investors. Coakley et al. (2021a) find that solo founders are less likely to raise more capital and complete a successful equity crowdfunding campaign than founder teams. Some other studies on equity crowdfunding investigate alternative measures of social capital. For instance, Ahlers et al. (2015) and Vismara (2016b) show that nonexecutives contribute little to funding outcomes. Vismara (2016a) specifies LinkedIn connections of proponents as an effective signal. Following Coakley et al. (2021a), we employ a solo founder dummy and expect it to have a negative association with funding outcome.

The last category represents venture-specific characteristics. Here, company age and its squared term are incorporated into the model. On the one hand, relatively mature companies might be conceived to be more likely to survive fierce competition and to generate profits and hence are more likely to be preferred by crowd investors. That is, company age might be positively related to the funding outcome. On the other hand, investors might think a mature company would be less capable of rapidly growing and generating large profits. This implies that the funding performance might increase with company age, yet the growth rate might start to decline from a certain value of company age. Existing studies mostly ignore the quadratic form and thereby rule out the possible curvilinear relationship. The literature thus reports inconsistent results about the influence of company age on the funding performance. For example, Ahlers et al. (2015) report that the years in business do not play a part in the number of investors or the funding amount, whereas Hornuf and Schwienbacher (2018) report a significant positive association between company age and the funding amount. Therefore, to avoid a potential multicollinearity bias, we use the demeaned value of company age as well as the square of the demeaned variable in the regression analysis.

Funding campaigns can differentiate across industry areas. Therefore, the categorical variable ISIC is used to code the industry branches of funding campaigns. This takes a value from 1 to 10 , consistent with the high-level ISIC (revision 4) aggregation A10. $G m b H$ is a dummy variable controlling for the different ventures' legal registration forms and corresponding common characteristics within each. The model employs a location dummy variable companyGermany to account for the country-specific characteristics of funding campaigns; for instance, for the regulatory difference between Germany and the other countries covered in the dataset, and the preference of crowd investors in favour of German companies. A venture is given a value of 1 if it is in Germany or 0 if it is in Austria. Government loan and award are variables capturing the official or public recognition the venture receives, which should be positively associated with the funding outcome. This is in line with previous research on the signalling effect of third-party endorsement on financing outcomes (Ralcheva \& Roosenboom, 2016). Patent is a dummy variable capturing the ventures' intellectual capital. In the literature, there exists evidence for the notion that patent ownership is significantly associated with venture performance, including total investment and late-stage financing (see, for instance, Mann \& Sager, 2007). Patent ownership can benefit ventures in the following ways (see, for instance, Ahlers et al., 2015; Long, 2002). First, it reduces information asymmetries between the venture and investors by signalling the venture's innovative capacity and future survival. Second, it deters potential market entrants. Ralcheva and Roosenboom (2016) underscore the positive influence of patents and similar intellectual property protections on funding outcomes. Vismara (2016b) confirms that patent ownership contributes to a venture attracting sophisticated investors at the early stage, although it does not play a role in the campaign success. In our propensity score matching model, we consider government loans, awards, and patent ownerships before the previous equity crowdfunding round started, thereby avoiding reverse causality problems with respect to the corresponding variables and the treatment variable Seasoned. Ventures are expected to continue their development path; therefore, match-weighted ventures should behave similarly in terms of their productivity, their ability to innovate, and their probabilities of receiving government loans or awards. In light of this consideration, these variables remain in the regression models.

Our main empirical models are designed as follows:

Weighted logit regression:

$$
\begin{aligned}
\text { Funding success }_{i} & =\alpha_{i}+\beta_{1 i} X_{\text {campaign-related }_{i}}+\beta_{2 i} X_{\text {venture promotion }_{i}} \\
& +\beta_{3 i} X_{\text {female ratio }_{i}}+\beta_{4 i} X_{\text {other entrepreneur-related }_{i}} \\
& +\beta_{5 i} X_{\text {venture-related }_{i}}+\varepsilon_{i}
\end{aligned}
$$


Table 1 Sample selection process

\begin{tabular}{|c|c|c|c|c|c|c|}
\hline & \multirow{2}{*}{$\begin{array}{l}\text { Platforms } \\
\text { No. }\end{array}$} & \multirow{2}{*}{$\begin{array}{l}\text { Campaigns } \\
\text { No. }\end{array}$} & \multicolumn{2}{|c|}{ Seasoned campaigns } & \multicolumn{2}{|c|}{ Target reached } \\
\hline & & & No. & Percentage & No. & Percentage \\
\hline Raw data & 21 & 411 & 37 & $9.0 \%$ & 156 & $38.0 \%$ \\
\hline Full information sample & 15 & 255 & 24 & $9.4 \%$ & 107 & $42.0 \%$ \\
\hline Initial offerings & 15 & 231 & - & - & 97 & $42.0 \%$ \\
\hline PS model input & 20 & 304 & 32 & $10.5 \%$ & 122 & $40.1 \%$ \\
\hline PS common support & 16 & 246 & 32 & $13.0 \%$ & 109 & $44.3 \%$ \\
\hline Post-match sample & 11 & 170 & 23 & $13.5 \%$ & 67 & $39.4 \%$ \\
\hline
\end{tabular}

Weighted multiple log-linear regression:

$$
\begin{aligned}
\operatorname{Ln}\left(\text { funding amount }_{i}\right) & =\alpha_{i}+\beta_{1 i} X_{\text {campaign-related }_{i}} \\
& +\beta_{2 i} X_{\text {venture promotion }_{i}}+\beta_{3 i} X_{\text {female ratio }_{i}} \\
& +\beta_{4 i} X_{\text {other entrepreneur-related }_{i}} \\
& +\beta_{5 i} X_{\text {venture-related }_{i}}+\varepsilon_{i}
\end{aligned}
$$

Weight-adjusted Poisson regression:

$$
\begin{aligned}
\operatorname{Ln}\left(\text { NoInvestors }_{i}\right) & =\alpha_{i}+\beta_{1 i} X_{\text {campaign-related }_{i}}+\beta_{2 i} X_{\text {venture promotion }_{i}} \\
& +\beta_{3 i} X_{\text {female ratio }_{i}}+\beta_{4 i} X_{\text {other entrepreneur-related }_{i}} \\
& +\beta_{5 i} X_{\text {venture-related }_{i}}+\varepsilon_{i}
\end{aligned}
$$

Propensity score matching:

$$
\begin{aligned}
\text { Seasoned }_{i} & =\alpha_{i}+\beta_{1 i} X_{\text {female ratio }_{i}} \\
& +\beta_{2 i} X_{\text {other entrepreneur-related }_{i}} \\
& +\beta_{3 i} X_{\text {venture-related }_{i}}+\varepsilon_{i}
\end{aligned}
$$

To circumvent potential endogeneity problems due to confounding variables and self-selection bias with respect to seasoned campaigns, we conduct biweight kernel propensity score matching using seasoned equity crowdfunding offering as a treatment variable. We use a logit model to estimate propensity scores for each venture based on female ratio, other entrepreneur-related variables, and venture-specific variables. Seasoned offerings are matched with initial offerings based on the kernel density of the propensity scores. Evoking the common support assumption, unmatched observations are discarded. Weights from propensity score matching reflect how observations enter into the matching process to create comparable treated and untreated groups. We integrate the weights in multiple regressions to control for potential selection bias related to seasoned offerings and to mitigate the endogeneity problem regarding entrepreneur-related and venture-related characteristics.

\subsection{Data and descriptive statistics}

The data employed in this study was hand collected from 22 German equity crowdfunding platforms, including currently active as well as discontinued ones. ${ }^{12}$ Thereby, it covers the majority of the German equity crowdfunding market for the period from each platform's inception, with the earliest records being from 2011 to November 2017. Overall, we identify 483 equity crowdfunding projects.

Table 1 provides an overview of the sample selection process. Our raw dataset consists of 411 campaigns on 21 platforms for which information on the funding amounts, thresholds, and targets is available. ${ }^{13}$ Out of these campaigns, 353 have reached the funding threshold, 156 have reached the funding target, and 37 are seasoned offerings. Then, we eliminate campaigns with missing data on any of the independent variables used in the regression models. A total of 255 campaigns on 15 platforms remain ${ }^{14} ; 231$ of which are first-time offerings. This "full information sample" is the basis of our analysis with respect to Hypothesis 1.

\footnotetext{
12 The sample includes data from the following platforms: Bankless24, Berlin Crowd, BestBC, Companisto, Conda, Crowd21 UG, DeutscheMikroinvest, Fundernation, Fundsters, Geldwerk1, Greenrocket, Gründerplus, Innovestment, Katrim, Microseeds24, Seed Experts, Seedmatch, Startkapital-Online, United Equity, Unternehmerich, Welcome Investment, and Welcome Startups.

${ }^{13}$ Only for the platform Microseeds24, none of the offerings met this requirement.

${ }^{14}$ Offerings on the following platforms were not included in our analysis due to missing data on the funding outcome variables or the independent variables: Crowd21 UG, DeutscheMikroinvest, Gründerplus, Innovestment, Katrim, and Unternehmerich.
} 
For the analysis of seasoned offerings, we start with 304 campaigns from the raw dataset for which complete information on venture-related and entrepreneur-related characteristics of the offerings are available. This enables us to conduct a biweight kernel propensity score-based match of the treated firms (seasoned offerings) and the control firms (initial offerings) with respect to venture- and entrepreneurspecific factors. Invoking the propensity score model's common support assumption reduces the sample by 58 campaigns ${ }^{15}$, and requiring complete information on all independent variables leads to the final post-match sample with 170 campaigns, out of which 23 are seasoned offerings.

The German Socio-Economic Panel Study (SOEP) provides longitudinal data on individuals' risk attitudes. Individuals report their willingness to take risks on an 11-point Likert scale ranging from 0 (risk averse) to 10 (fully risk taking). Based on these selfassessed data (version 33.1, waves 2009 and 2014), we estimated domain-general risk-taking propensities for the self-employed by gender and in 10-year age cohorts. To control for population trends in domaingeneral risk attitudes and to avoid potential reverse causality problems, we employed estimates from Wave 2009 for entrepreneurs seeking equity crowdfunding by 2014 and estimates from Wave 2014 for those starting funding campaigns in 2014 or later.

Table 2 reports the descriptive statistics of the funding outcome variables separately for ventures with and without female managing directors. It also displays the results of the equality of means tests, that is, two-tailed $t$-tests assuming unequal variance taking into account the sampling weights with respect to successful campaigns. The data show that, on average, ventures with female managing directors raise less capital from fewer crowd investors in equity crowdfunding. Moreover, they are more successful in terms of reaching their funding target. This might be attributed to the fact that they set a lower funding target compared to their counterparts (€242,159 versus €343,133). However, differences in funding outcomes are not statistically significant between ventures with and without female managing

\footnotetext{
15 As Online Appendix A.4 shows, the matching approach is successful in the sense that after controlling for the predicted probability of prior equity-based crowdfunding experience, the coefficients associated with the venture-specific and managing director-related characteristics are not significant anymore.
}

directors. Overall, except for the funding status, the funding outcome variables tended to be more clustered around their mean values among ventures with female managing directors. In initial offerings, ventures with female managing directors do not differ significantly from their male-led peers in any of the three dimensions of funding outcome. In contrast, in the case of seasoned offerings, ventures with female managing directors do not differ significantly in their probability of being funded, but on average, they seem to raise less capital and attract fewer investors. ${ }^{16}$

Panel A of Table 3 (columns 2-6) reports the descriptive statistics for the final sample. ${ }^{17}$ On average, each equity-based crowdfunding campaign raised about $€ 0.25$ million from 304 crowd investors during the observation period. This implies that about $81.69 \%$ of its target was reached. In total, $38.0 \%$ of the campaigns were successful in terms of reaching their funding target, and $€ 62.52$ million had been invested in equity-based crowdfunding. Funding thresholds averaged $€ 67,474$. Of those, $9.4 \%$ are seasoned offerings. Also, $17.3 \%$ of the campaigns had extended the pre-determined funding window, while $84.8 \%$ of the campaigns had been promoted on one of the five big platforms. Considering the financing instrument, 27 campaigns in the final sample used participation rights, while an overwhelming proportion of campaigns relied on profit-participating subordinated loans. This is consistent with the comparative regulatory advantages of profit-participating subordinated loans over the other options. Also, $52.2 \%$ of the campaigns provided bonuses to crowd investors. The year 2011 was the first year with notable equity-based crowdfunding activity in Germany, while 24 of the campaigns ended in 2012, and 43 to 50 campaigns per year ended during the period from 2013 to 2016. By November 2017, 42 campaigns were pursuing equitybased crowdfunding. These figures are in accordance with the original sample as well as the general market development. The market experienced substantial

\footnotetext{
16 To account for a potential small sample bias in the $t$-test, we also conduct a nonparametric Wilcoxon Mann-Whitney ranksum test in case of the seasoned offerings sample, leading to a drop in significance for the number of investors to the $10 \%$ level.

17 Descriptive statistics for the initial offering sample and for the post-match sample are included in the Online Appendix, Section A.2.
} 


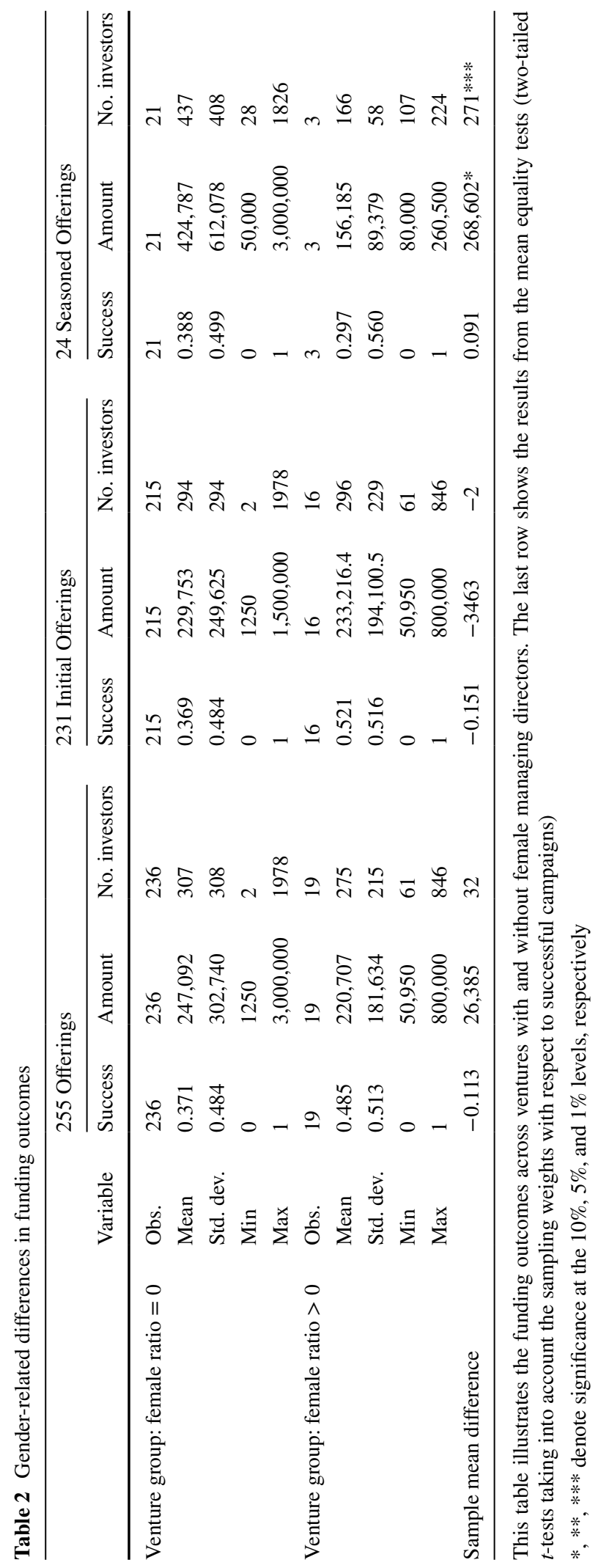


Table 3 Descriptive statistics for the full-information sample

\begin{tabular}{|c|c|c|c|c|c|c|c|c|}
\hline \multirow[b]{2}{*}{ Variable } & \multicolumn{5}{|l|}{ Panel A } & \multicolumn{3}{|l|}{ Panel B } \\
\hline & Mean & Median & Std. Dev. & Min & Max & Mean_initial & Mean_seasoned & Mean equality \\
\hline Funding success & 0.380 & 0 & 0.486 & 0 & 1 & 0.380 & 0.377 & 0.003 \\
\hline Funding amount & $245,160.7$ & 150,000 & $295,397.8$ & 1250 & $3,000,000$ & $230,026.3$ & $390,752.2$ & $-160,725.9$ \\
\hline Ln(funding amount) & 11.926 & 11.918 & 1.017 & 7.131 & 14.914 & 11.883 & 12.333 & $-0.450^{* *}$ \\
\hline NoInvestors & 304.244 & 192 & 301.531 & 2 & 1978 & 294.014 & 402.653 & -108.638 \\
\hline \multicolumn{9}{|l|}{ Funding campaign } \\
\hline Funding target & $335,741.1$ & 250,000 & $451,591.900$ & 10,000 & $5,000,000$ & $329,256.9$ & $398,118.6$ & $-133,012.6$ \\
\hline Funding threshold & $67,474.960$ & 50,000 & $43,305.640$ & 10,000 & 450,000 & $68,478.040$ & $57,825.4$ & $18,729.910^{*}$ \\
\hline Ln(funding threshold) & 10.962 & 10.820 & 0.565 & 9.210 & 13.017 & 10.972 & 10.863 & 0.109 \\
\hline Seasoned & 0.094 & 0 & 0.293 & 0 & 1 & 0 & 1 & -1.000 \\
\hline Campaign extended & 0.173 & 0 & 0.379 & 0 & 1 & 0.174 & 0.164 & 0.010 \\
\hline Platform big & 0.848 & 1 & 0.360 & 0 & 1 & 0.837 & 0.955 & $-0.119 * *$ \\
\hline \multicolumn{9}{|l|}{ FI } \\
\hline Participation right & 0.106 & 0 & 0.309 & 0 & 1 & 0.095 & 0.216 & -0.121 \\
\hline Subordinated loan & 0.042 & 0 & 0.202 & 0 & 1 & 0.047 & 0 & $0.047 * * *$ \\
\hline $\begin{array}{l}\text { Profit-participating } \\
\text { subordinated loan }\end{array}$ & 0.756 & 1 & 0.431 & 0 & 1 & 0.761 & 0.702 & 0.059 \\
\hline Silent partnership & 0.096 & 0 & 0.295 & 0 & 1 & 0.098 & 0.082 & 0.015 \\
\hline Other bonus & 0.522 & 1 & 0.501 & 0 & 1 & 0.525 & 0.493 & 0.032 \\
\hline \multicolumn{9}{|l|}{ Campaign end year } \\
\hline 2011 & 0.011 & 0 & 0.106 & 0 & 1 & 0.012 & 0 & $0.012^{*}$ \\
\hline 2012 & 0.093 & 0 & 0.291 & 0 & 1 & 0.099 & 0.038 & 0.061 \\
\hline 2013 & 0.173 & 0 & 0.379 & 0 & 1 & 0.161 & 0.291 & -0.130 \\
\hline 2014 & 0.169 & 0 & 0.375 & 0 & 1 & 0.164 & 0.209 & -0.044 \\
\hline 2015 & 0.195 & 0 & 0.397 & 0 & 1 & 0.190 & 0.247 & -0.057 \\
\hline 2016 & 0.193 & 0 & 0.396 & 0 & 1 & 0.200 & 0.134 & 0.066 \\
\hline 2017 & 0.165 & 0 & 0.372 & 0 & 1 & 0.174 & 0.082 & 0.092 \\
\hline \multicolumn{9}{|l|}{ Venture promotion } \\
\hline Description length & 14.921 & 14.640 & 9.560 & 0 & 83.846 & 14.413 & 19.799 & -5.386 \\
\hline Video length & 5.288 & 4.617 & 6.612 & 0 & 78.183 & 5.315 & 5.032 & 0.283 \\
\hline No of photos & 23.434 & 22 & 15.012 & 0 & 85 & 22.848 & 29.072 & $-6.224^{*}$ \\
\hline \multicolumn{9}{|c|}{ Entrepreneur characteristics } \\
\hline Female ratio & 0.059 & 0 & 0.222 & 0 & 1 & 0.053 & 0.127 & -0.074 \\
\hline Solo founder & 0.378 & 0 & 0.486 & 0 & 1 & 0.378 & 0.380 & -0.002 \\
\hline Risk propensity & 5.555 & 5.733 & 0.593 & 3.708 & 6.287 & 5.567 & 5.441 & 0.126 \\
\hline Age_mean & 39.740 & 38 & 9.520 & 23 & 71 & 40.079 & 36.486 & $3.592 * *$ \\
\hline Education_Dr & 0.119 & 0 & 0.324 & 0 & 1 & 0.119 & 0.120 & -0.001 \\
\hline \multicolumn{9}{|l|}{ Venture characteristics } \\
\hline Company age & 2.805 & 2 & 3.634 & 0 & 34 & 2.803 & 2.829 & -0.026 \\
\hline Company age2 & 21.022 & 4 & 91.995 & 0 & 1156 & 22.027 & 11.363 & 10.664 \\
\hline Government loan & 0.032 & 0 & 0.175 & 0 & 1 & 0.030 & 0.045 & -0.014 \\
\hline Award & 0.260 & 0 & 0.440 & 0 & 1 & 0.248 & 0.380 & -0.132 \\
\hline Patent & 0.134 & 0 & 0.341 & 0 & 1 & 0.130 & 0.171 & -0.042 \\
\hline 2. ISIC & 0.185 & 0 & 0.389 & 0 & 1 & 0.195 & 0.089 & 0.106 \\
\hline 3. ISIC & 0.016 & 0 & 0.126 & 0 & 1 & 0.018 & 0 & $0.018 * *$ \\
\hline 4. ISIC & 0.272 & 0 & 0.446 & 0 & 1 & 0.266 & 0.329 & -0.063 \\
\hline
\end{tabular}


Table 3 (continued)

\begin{tabular}{|c|c|c|c|c|c|c|c|c|}
\hline \multirow[b]{2}{*}{ Variable } & \multicolumn{5}{|c|}{ Panel A } & \multicolumn{3}{|l|}{ Panel B } \\
\hline & Mean & Median & Std. Dev. & Min & Max & Mean_initial & Mean_seasoned & Mean equality \\
\hline 5. ISIC & 0.295 & 0 & 0.457 & 0 & 1 & 0.277 & 0.462 & $-0.185 *$ \\
\hline 6. ISIC & 0.023 & 0 & 0.151 & 0 & 1 & 0.022 & 0.038 & -0.016 \\
\hline 8. ISIC & 0.159 & 0 & 0.366 & 0 & 1 & 0.167 & 0.082 & 0.084 \\
\hline 9. ISIC & 0.008 & 0 & 0.088 & 0 & 1 & 0.009 & 0 & 0.009 \\
\hline 10. ISIC & 0.042 & 0 & 0.202 & 0 & 1 & 0.047 & 0 & $0.047 * * * *$ \\
\hline $\mathrm{GmbH}$ & 0.883 & 1 & 0.323 & 0 & 1 & 0.870 & 1 & $-0.130 * * * *$ \\
\hline CompanyGermany & 0.752 & 1 & 0.433 & 0 & 1 & 0.752 & 0.753 & -0.002 \\
\hline
\end{tabular}

Panel A (columns 2-6) presents descriptive statistics of the variables for the full-information sample consisting of 231 initial offerings and 24 seasoned offerings. Panel B (columns 7-9) shows the mean values of the variables for initial and seasoned offerings. It also reports the results from the mean equality tests (two-tailed $t$-tests taking into account sampling weights with respect to successful campaigns). See Section 3.2, or Online Appendix A.1, for variable definition

$*, * *, * * *, * * * *$ denote significance at the $10 \%, 5 \%, 1 \%$, and $0.1 \%$ levels, respectively

growth in 2012 and 2013, remained relatively stable until 2016, and then seemed to cool down in 2017. All the campaigns in the final sample employed an Allor-Nothing financing model, and hence the financing model did not have to be controlled for in the regression analysis.

An average campaign posted 23.43 photos on the platform website, while the length of the promotion videos averaged $5.29 \mathrm{~min}$. On average, the venture descriptions' length was 14,921 characters.

The average founder team consists of about two people. A total of $37.8 \%$ of venture observations have a solo founder. Among these solo founder ventures, 95\% have a male founder, whereas only around $5 \%$ have a female founder. Among the ventures with multiple founders, $83 \%$ have only male managing directors, $14 \%$ have team of both male and female managing directors, and around $3 \%$ are led only by female entrepreneurs. Founder managing directors exhibit a medium domain-general risktaking propensity value of 5.56 on a score from 0 (risk averse) to 10 (total risk taking). On average, the managing directors were 40 years old at the beginning of the funding campaign. Only $6.0 \%$ of the managing directors are females, while $11.9 \%$ hold a doctoral degree.

The average venture age is 2.81 years, confirming that young ventures are the main participants in the equity crowdfunding market. The fund-raising ventures in our dataset most frequently belong to the ISIC industry categories: "Wholesale and retail trade, transportation and storage, accommodation and food service activities", and "Information and communication".
Most ventures operate as limited liability companies (German "GmbH"), with 192 ventures located in Germany, while the rest are from Austria. Only $3.2 \%$ of the campaigns had received financial government support at the beginning of the campaign. Also, 66 ventures had received awards, and 34 ventures own patents.

Panel B of Table 3 (columns 7-9) presents the mean values of the variables for initial and seasoned offerings. It also shows the results from the mean equality tests. As panel B shows, seasoned offerings on average attract more capital and more crowd investors. However, as they set larger targets, campaigns are less likely to be successful. The minimum level of capital is set substantially lower in seasoned offerings (significant at the $10 \%$ level). Ventures in seasoned offerings employ subordinated loans less often, and selected big platforms for their pitch more often. They also feature longer descriptions and contain more images (significant at the $10 \%$ level), while their pitch videos are shorter. The female ratio is $12.7 \%$. In contrast, the female ratio of ventures in initial offerings is $5.3 \%$. Seasoned offerings possess more indicators of high quality, as they are more likely to be initiated by entrepreneurs holding a doctoral degree, to own patents, and to have received government loans and awards. At the same time, they are more homogeneous in terms of entrepreneurs' risk attitude and age, ventures' legal form, industry, and years in business. Particularly, they overwhelmingly belong to the ISIC industry categories: "Wholesale and retail trade, transportation 

and promotion-related determinants of funding outcome

This table shows the results about the campaignand promotion-related determinants of the funding outcome in initial offerings. Model 1 employs the logit method in which the funding success dummy is the dependent variable. Model 2 conducts a multiple log-linear regression on the natural logarithm of the funding amount, while model 3 employs the Poisson method in which the number of investors is the dependent variable. Independent variables are defined in Section 3.2.

All three models incorporate sampling weights with respect to successful campaigns. Heteroscedasticityconsistent (robust) standard errors are reported in parentheses

$*, * *, * * *, * * * *$ denote significance at the $10 \%$, $5 \%, 1 \%$, and $0.1 \%$ levels, respectively
Table 4 Campaign-related

\begin{tabular}{|c|c|c|c|}
\hline Dependent variables & $\begin{array}{l}\text { Model } 1 \\
\text { Funding success }\end{array}$ & $\begin{array}{l}\text { Model } 2 \\
\text { Ln(funding amount) }\end{array}$ & $\begin{array}{l}\text { Model } 3 \\
\text { NoInvestors }\end{array}$ \\
\hline \multicolumn{4}{|l|}{ Campaign-related } \\
\hline Campaign extended & $\begin{array}{l}0.146 \\
{[0.428]}\end{array}$ & $\begin{array}{l}0.207 \\
{[0.142]}\end{array}$ & $\begin{array}{l}0.151 \\
{[0.120]}\end{array}$ \\
\hline Platform big & $\begin{array}{l}1.868 * * * \\
{[0.627]}\end{array}$ & $\begin{array}{l}0.874 * * * * \\
{[0.147]}\end{array}$ & $\begin{array}{l}1.659 * * * * \\
{[0.145]}\end{array}$ \\
\hline Ln(funding threshold) & $\begin{array}{l}-0.151 \\
{[0.326]}\end{array}$ & $\begin{array}{l}0.525 * * * * \\
{[0.119]}\end{array}$ & $\begin{array}{l}0.315 * * * * \\
{[0.0873]}\end{array}$ \\
\hline 3.FI & $\begin{array}{l}-0.274 \\
{[0.478]}\end{array}$ & $\begin{array}{l}-0.128 \\
{[0.110]}\end{array}$ & $\begin{array}{l}0.190 \\
{[0.130]}\end{array}$ \\
\hline Other bonus & $\begin{array}{l}0.245 \\
{[0.325]}\end{array}$ & $\begin{array}{l}0.220^{* *} \\
{[0.100]}\end{array}$ & $\begin{array}{l}-0.537^{* * * * *} \\
{[0.107]}\end{array}$ \\
\hline \multicolumn{4}{|l|}{ Promotion-related } \\
\hline Description length & $\begin{array}{l}0.0418^{*} \\
{[0.0231]}\end{array}$ & $\begin{array}{l}0.0350 * * * * \\
{[0.00778]}\end{array}$ & $\begin{array}{l}0.0408 * * * * \\
{[0.00584]}\end{array}$ \\
\hline Video length & $\begin{array}{l}0.00232 \\
{[0.0171]}\end{array}$ & $\begin{array}{l}0.00933 * * * \\
{[0.00349]}\end{array}$ & $\begin{array}{l}0.00261 \\
{[0.00346]}\end{array}$ \\
\hline No of photos & $\begin{array}{l}-0.0225 \\
{[0.0153]}\end{array}$ & $\begin{array}{l}0.00679 \\
{[0.00436]}\end{array}$ & $\begin{array}{l}0.00142 \\
{[0.00398]}\end{array}$ \\
\hline Constant & $\begin{array}{l}0.350 \\
{[3.673]}\end{array}$ & $\begin{array}{l}4.606 * * * * \\
{[1.298]}\end{array}$ & $\begin{array}{l}-0.488 \\
{[0.940]}\end{array}$ \\
\hline Campaign end year & Yes & Yes & Yes \\
\hline $\mathrm{N}$ & 231 & 231 & 231 \\
\hline $\begin{array}{l}\mathrm{LR} \text { test } p \text {-value } \\
\text { ddiusted } R^{2}\end{array}$ & 0.0000 & $\begin{array}{l}0.0000 \\
0.479\end{array}$ & 0.0000 \\
\hline $\begin{array}{l}\text { Adjusted } R^{2} \\
\text { Pseudo } R^{2}\end{array}$ & 0.198 & 0.479 & 0.526 \\
\hline AIC & 275.9 & 524.6 & $26,257.1$ \\
\hline BIC & 327.5 & 576.3 & $26,308.8$ \\
\hline
\end{tabular}

and storage, accommodation and food service activities" (32.9\%) and "Information and communication" (46.2\%). Notably, ventures in seasoned offerings do not set as wide a range of funding thresholds as their counterparts do. Overall, seasoned offerings seem to differ substantially from initial offerings. However, it is not clear whether the gender of the members of the top management team also plays a role in explaining differences in venture performance.

\section{Findings}

4.1 Determinants of funding outcome in initial offerings

In this section, we examine whether entrepreneurial characteristics-and, in particular, gender-have a bearing on funding success in initial equity crowdfunding offerings after controlling for differences in the ventures, campaigns, and promotion characteristics. Models 1-3 in Table 4 show that the two categories of independent variables that are related to features of funding campaigns and venture promotions have a statistically significant explanatory power with respect to the success of initial offerings. For instance, these variables can explain $47.9 \%$ of the variations in the funding amount. In particular, 

related and venture-related determinants of funding outcome
Table 5 Entrepreneur-
This table reports the results about the entrepreneur- and venturerelated determinants of the funding outcome in initial offerings. Model 4 employs the logit method in which the funding success dummy is the dependent variable. Model 5 and model 6 conduct a multiple log-linear regression and a Poisson regression in which the dependent variables are the natural logarithm of the funding amount and the number of investors, respectively. Independent variables are defined in Section 3.2.

All the regressions incorporate the sampling weights with respect to successful campaigns. Heteroscedasticityconsistent (robust) standard errors are reported in parentheses

$*$, **, ***, **** denote significance at the $10 \%$, $5 \%, 1 \%$, and $0.1 \%$ levels, respectively

\begin{tabular}{|c|c|c|c|}
\hline Dependent variables & $\begin{array}{l}\text { Model } 4 \\
\text { Funding success }\end{array}$ & $\begin{array}{l}\text { Model } 5 \\
\text { Ln(funding amount) }\end{array}$ & $\begin{array}{l}\text { Model } 6 \\
\text { NoInvestors }\end{array}$ \\
\hline \multicolumn{4}{|l|}{ Entrepreneur-related } \\
\hline Female ratio & $\begin{array}{l}0.328 \\
{[0.777]}\end{array}$ & $\begin{array}{l}0.541 * * \\
{[0.245]}\end{array}$ & $\begin{array}{l}0.0357 \\
{[0.264]}\end{array}$ \\
\hline Solo founder & $\begin{array}{l}-0.170 \\
{[0.330]}\end{array}$ & $\begin{array}{l}-0.292 * * \\
{[0.147]}\end{array}$ & $\begin{array}{l}-0.384 * * * \\
{[0.149]}\end{array}$ \\
\hline Risk propensity & $\begin{array}{l}-0.454 \\
{[0.278]}\end{array}$ & $\begin{array}{l}0.354 * * * \\
{[0.122]}\end{array}$ & $\begin{array}{l}0.163 \\
{[0.124]}\end{array}$ \\
\hline Age_mean & $\begin{array}{l}-0.0627 * * * \\
{[0.0197]}\end{array}$ & $\begin{array}{l}0.00501 \\
{[0.00800]}\end{array}$ & $\begin{array}{l}-0.00611 \\
{[0.00658]}\end{array}$ \\
\hline Education_Dr & $\begin{array}{l}0.622 \\
{[0.474]}\end{array}$ & $\begin{array}{l}0.272 \\
{[0.175]}\end{array}$ & $\begin{array}{l}0.207 \\
{[0.178]}\end{array}$ \\
\hline \multicolumn{4}{|l|}{ Venture-related } \\
\hline Company age & $\begin{array}{l}-0.0130 \\
{[0.0941]}\end{array}$ & $\begin{array}{l}0.111 * * * \\
{[0.0355]}\end{array}$ & $\begin{array}{l}0.0738^{* *} \\
{[0.0352]}\end{array}$ \\
\hline Company age2 & $\begin{array}{l}-0.00161 \\
{[0.00384]}\end{array}$ & $\begin{array}{l}-0.00557 * * * * \\
{[0.00149]}\end{array}$ & $\begin{array}{l}-0.00494 * * \\
{[0.00202]}\end{array}$ \\
\hline Government loan & $\begin{array}{l}-0.496 \\
{[0.729]}\end{array}$ & $\begin{array}{l}-0.231 \\
{[0.261]}\end{array}$ & $\begin{array}{l}-0.148 \\
{[0.248]}\end{array}$ \\
\hline Award & $\begin{array}{l}0.200 \\
{[0.333]}\end{array}$ & $\begin{array}{l}0.364 * * * \\
{[0.135]}\end{array}$ & $\begin{array}{l}0.0930 \\
{[0.127]}\end{array}$ \\
\hline Patent & $\begin{array}{l}0.456 \\
{[0.479]}\end{array}$ & $\begin{array}{l}0.341^{* *} \\
{[0.158]}\end{array}$ & $\begin{array}{l}-0.000807 \\
{[0.184]}\end{array}$ \\
\hline Constant & $\begin{array}{l}3.809^{*} \\
{[1.955]}\end{array}$ & $\begin{array}{l}9.793 * * * * \\
{[0.855]}\end{array}$ & $\begin{array}{l}4.832 * * * * \\
{[0.784]}\end{array}$ \\
\hline ISIC & Yes & Yes & Yes \\
\hline $\mathrm{GmbH}$ & Yes & Yes & Yes \\
\hline CompanyGermany & Yes & Yes & Yes \\
\hline $\mathrm{N}$ & 231 & 231 & 231 \\
\hline LR test $p$-value & 0.0620 & 0.0000 & 0.0000 \\
\hline Adjusted $R^{2}$ & & 0.147 & \\
\hline Pseudo $R^{2}$ & 0.104 & & 0.190 \\
\hline AIC & 314.9 & 643.3 & $44,846.7$ \\
\hline BIC & 383.7 & 712.1 & $44,915.5$ \\
\hline
\end{tabular}

the platform choice seems to have a positive and significant influence on the funding outcome. Ventures setting a larger threshold raise more capital from more crowd investors. However, they are not more likely to reach their target. In addition, the length of description has a positive effect on the likelihood of completing a successful initial campaign, the funding amount, and the number of investors. Further, ventures presenting longer pitch videos tend to raise a larger amount of capital in their initial campaigns. While offering investors extra bonuses helps ventures raise more capital, it has a negative effect on crowd participation.

Table 5 presents the regression results with respect to the entrepreneurial and venture-related characteristics. Model 4 reports a significant negative effect of the entrepreneurs' age on the likelihood of completing a successful initial offering. As model 5 shows, $14.7 \%$ of the variance in the funding amount can be explained by these factors. In particular, the entrepreneur's risk-taking attitude and the venture's age, awards received and patent 
Table 6 Results of the multiple regression analysis on initial campaigns

\begin{tabular}{|c|c|c|c|c|c|c|}
\hline Dependent variable & $\begin{array}{l}\text { Model } 7 \\
\text { Funding success }\end{array}$ & $\begin{array}{l}\text { Model } 8 \\
\text { Ln(funding amount) }\end{array}$ & $\begin{array}{l}\text { Model } 9 \\
\text { NoInvestors }\end{array}$ & $\begin{array}{l}\text { Model } 10 \\
\text { Funding success }\end{array}$ & $\begin{array}{l}\text { Model } 11 \\
\text { Ln(funding amount) }\end{array}$ & $\begin{array}{l}\text { Model } 12 \\
\text { NoInvestors }\end{array}$ \\
\hline \multicolumn{7}{|l|}{ Entrepreneur-related } \\
\hline Female ratio & $\begin{array}{l}1.539 \\
{[1.226]}\end{array}$ & $\begin{array}{l}0.340 \\
{[0.288]}\end{array}$ & $\begin{array}{l}0.230 \\
{[0.257]}\end{array}$ & $\begin{array}{l}-53.83 * * * \\
{[19.71]}\end{array}$ & $\begin{array}{l}-1.253 \\
{[3.639]}\end{array}$ & $\begin{array}{l}0.627 \\
{[3.484]}\end{array}$ \\
\hline Solo founder & $\begin{array}{l}-0.0309 \\
{[0.373]}\end{array}$ & $\begin{array}{l}-0.188^{*} \\
{[0.112]}\end{array}$ & $\begin{array}{l}-0.263 * * \\
{[0.108]}\end{array}$ & $\begin{array}{l}-0.0334 \\
{[0.373]}\end{array}$ & $\begin{array}{l}-0.188^{*} \\
{[0.113]}\end{array}$ & $\begin{array}{l}-0.263^{* *} \\
{[0.108]}\end{array}$ \\
\hline Risk propensity & $\begin{array}{l}0.789 \\
{[1.038]}\end{array}$ & $\begin{array}{l}0.0773 \\
{[0.263]}\end{array}$ & $\begin{array}{l}0.201 \\
{[0.234]}\end{array}$ & $\begin{array}{l}0.305 \\
{[1.113]}\end{array}$ & $\begin{array}{l}0.0572 \\
{[0.283]}\end{array}$ & $\begin{array}{l}0.204 \\
{[0.243]}\end{array}$ \\
\hline Age_mean & $\begin{array}{l}-0.0224 \\
{[0.0285]}\end{array}$ & $\begin{array}{l}0.000795 \\
{[0.00724]}\end{array}$ & $\begin{array}{l}0.000383 \\
{[0.00737]}\end{array}$ & $\begin{array}{l}-0.0297 \\
{[0.0283]}\end{array}$ & $\begin{array}{l}0.000431 \\
{[0.00747]}\end{array}$ & $\begin{array}{l}0.000399 \\
{[0.00738]}\end{array}$ \\
\hline Education_Dr & $\begin{array}{l}0.984 * \\
{[0.566]}\end{array}$ & $\begin{array}{l}0.250 \\
{[0.153]}\end{array}$ & $\begin{array}{l}0.173 \\
{[0.134]}\end{array}$ & $\begin{array}{l}0.732 \\
{[0.594]}\end{array}$ & $\begin{array}{l}0.242 \\
{[0.158]}\end{array}$ & $\begin{array}{l}0.174 \\
{[0.139]}\end{array}$ \\
\hline \multicolumn{7}{|l|}{ Campaign-related } \\
\hline Platform big & $\begin{array}{l}2.446 * * * * \\
{[0.712]}\end{array}$ & $\begin{array}{l}0.948 * * * * \\
{[0.166]}\end{array}$ & $\begin{array}{l}1.893 * * * * \\
{[0.165]}\end{array}$ & $\begin{array}{l}2.657 * * * * \\
{[0.763]}\end{array}$ & $\begin{array}{l}0.950 * * * * \\
{[0.167]}\end{array}$ & $\begin{array}{l}1.892 * * * * \\
{[0.166]}\end{array}$ \\
\hline Ln(funding threshold) & $\begin{array}{l}-0.596 \\
{[0.416]}\end{array}$ & $\begin{array}{l}0.440 * * * * \\
{[0.120]}\end{array}$ & $\begin{array}{l}0.141 \\
{[0.102]}\end{array}$ & $\begin{array}{l}-0.747^{*} \\
{[0.424]}\end{array}$ & $\begin{array}{l}0.436 * * * * \\
{[0.123]}\end{array}$ & $\begin{array}{l}0.143 \\
{[0.104]}\end{array}$ \\
\hline $\begin{array}{l}\text { Female ratio \# } \\
\ln \text { (funding threshold) }\end{array}$ & & & & $\begin{array}{l}4.944 * * * \\
{[1.766]}\end{array}$ & $\begin{array}{l}0.143 \\
{[0.323]}\end{array}$ & $\begin{array}{l}-0.0355 \\
{[0.309]}\end{array}$ \\
\hline AME female ratio & 0.254 & 0.340 & 67.601 & 0.100 & 0.313 & 68.566 \\
\hline Constant & $\begin{array}{l}-0.0792 \\
{[6.967]}\end{array}$ & $\begin{array}{l}5.285^{* * * *} \\
{[1.874]}\end{array}$ & $\begin{array}{l}0.161 \\
{[1.723]}\end{array}$ & $\begin{array}{l}4.295 \\
{[7.526]}\end{array}$ & $\begin{array}{l}5.449 * * * \\
{[2.066]}\end{array}$ & $\begin{array}{l}0.128 \\
{[1.836]}\end{array}$ \\
\hline Other campaign-related & Yes & Yes & Yes & Yes & Yes & Yes \\
\hline Promotion-related & Yes & Yes & Yes & Yes & Yes & Yes \\
\hline Venture-related & Yes & Yes & Yes & Yes & Yes & Yes \\
\hline $\mathrm{N}$ & 231 & 231 & 231 & 231 & 231 & 231 \\
\hline LR test $p$-value & 0.0002 & 0.0000 & 0.0000 & 0.0001 & 0.0000 & 0.0000 \\
\hline Adjusted $R^{2}$ & & 0.483 & & & 0.481 & \\
\hline Pseudo $R^{2}$ & 0.258 & & 0.618 & 0.273 & & 0.618 \\
\hline AIC & 295.7 & 539.6 & $21,169.6$ & 293.0 & 541.5 & $21,170.9$ \\
\hline $\mathrm{BIC}$ & 412.7 & 656.6 & $21,286.6$ & 413.4 & 662.0 & $21,291.4$ \\
\hline
\end{tabular}

This table shows the results from the weighted multiple regression models. Models 7 and 10 employ the logit method in which the dependent variables are the funding success dummy. Models 8 and 11 are based on multiple log-linear regressions. The dependent variable is the natural logarithm of the funding amount. Models 9 and 12 are Poisson regressions with the number of investors as the dependent variable. Independent variables are defined in Section 3.2. Average marginal effects (AMEs) of female ratio are also reported. The regressions incorporate the sampling weights with respect to successful campaigns. Heteroscedasticity-consistent (robust) standard errors are reported in parentheses

$*, * *, * * *, * * * *$ denote significance at the $10 \%, 5 \%, 1 \%$, and $0.1 \%$ levels, respectively

ownership have significant positive effects on the funding amount. female ratio is positively associated with the funding amount, while solo founder negatively influences the funding amount. Model 6 also shows that having a team of founders and having a more mature venture contribute to attracting more crowd funders.
Table 6 summarizes the results for our main models based on the weighted initial offering sample. Models 7, 8, and 9 investigate factors affecting the funding outcome in terms of funding success, the funding amount, and number of investors, respectively. We conduct a weight-adjusted logit regression in model 7 and a weighted multiple log-linear 
Fig. 1 Average marginal effects plot for the initial offering sample. This figure shows the average marginal effects of female ratio across percentiles of In(funding threshold) based on the initial offering sample. The grey area indicates the $95 \%$ confidence interval

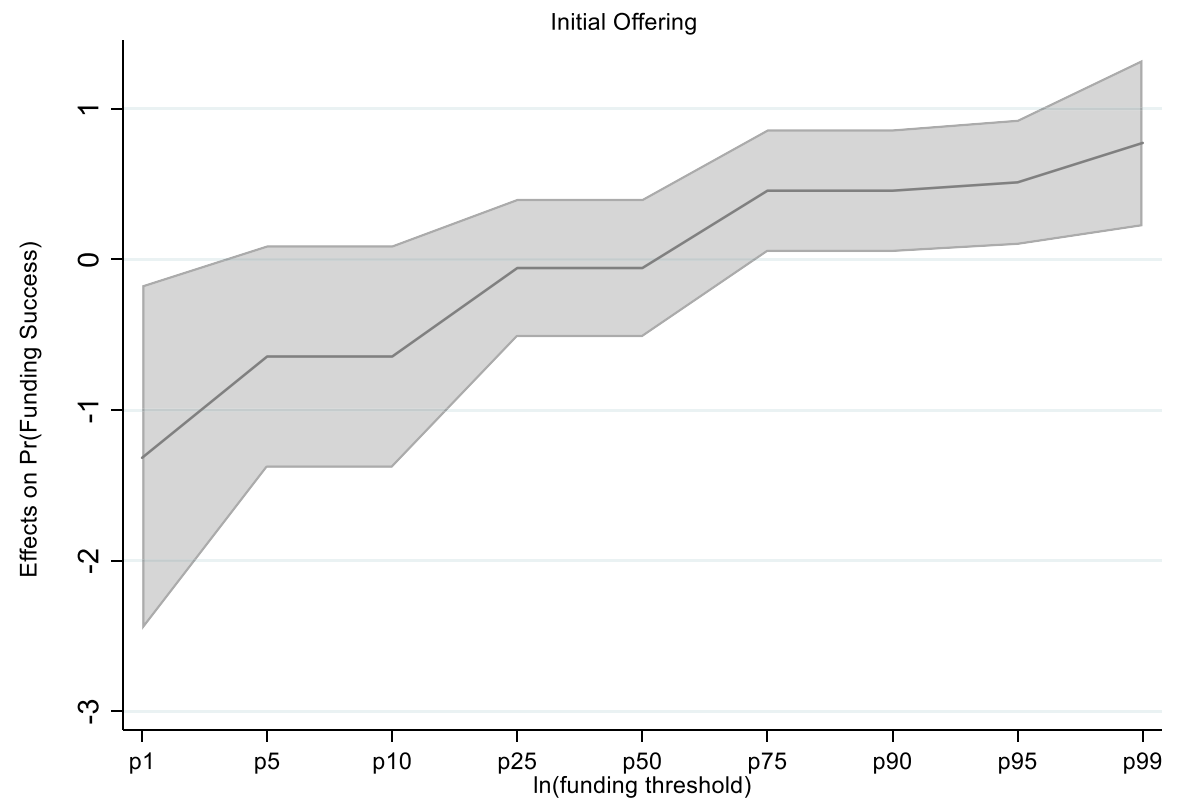

regression in model 8. Model 9 shows results based on a weight-adjusted Poisson regression model. The insignificant coefficients of female ratio indicate that there may indeed be a democratising effect of equity crowdfunding. Ventures with more female managing directors do not attract a significantly lower amount of capital or significantly fewer crowd investors. They are not less likely to reach their target either. The average marginal effect of female ratio is also not statistically significant. Hence, the empirical evidence supports Hypothesis 1.

The solo founder dummy is significantly negatively associated with the number of investors and it shows a weakly negative effect on the amount of capital raised (significant at the $10 \%$ level). These results suggest that the perceived benefits, such as cumulative social capital, outweigh the perceived potential process losses, relational losses, and other negative aspects associated with a larger founder team. Managing directors' risk-taking attitudes and age do not seem to play an important role with respect to the funding outcome. Crowd investors respond slightly positively to the managing directors holding a doctoral degree. A higher funding threshold tends to attract more funding, though it does not seem to induce more crowd participation and contributes little to reaching the target. Ventures significantly benefit from posting their campaigns on a big platform. Longer descriptions help them attract more funds and more investors. All the three regression models are overall significant at the $0.1 \%$ level. In particular, model 8 can explain $48.3 \%$ of the variations in the funding amount, while the pseudo $R^{2}$ of model 7 and model 9 is $25.8 \%$ and $61.8 \%$, respectively.

To examine whether the effect of the managing directors' gender depends on the pre-determined funding threshold and implicitly the initial capital needs, we include an interaction between female ratio and $\ln$ (funding threshold). The average marginal effect of female ratio remains insignificant in all three models. The coefficient on the interaction term is significant only in model 10. It implies that ventures with more female managing directors significantly benefit more from setting a higher funding threshold in terms of a higher likelihood of success. At the same time, the coefficient on female ratio turns negative and significant at the $1 \%$ level, which suggests a moderating role of the funding threshold (that is, the initial capital need) on the gender-related disparities in equity crowdfunding. The negative coefficient of $\ln$ (funding threshold) shows that male managing directors have a slightly lower likelihood of success when setting a higher funding threshold (significant at the $10 \%$ level). The pseudo $R^{2}$ of model 10 increases, indicating that it has a larger explanatory power with respect to the funding success variable.

Figure 1 illustrates how the average marginal effects of female ratio vary across percentiles of 
Table 7 Results of the multiple regression analysis on matched campaigns

\begin{tabular}{|c|c|c|c|c|c|c|}
\hline \multirow{3}{*}{ Dependent variable } & \multicolumn{2}{|l|}{ Model 13} & \multicolumn{2}{|l|}{ Model 14} & \multicolumn{2}{|l|}{ Model 15} \\
\hline & \multicolumn{2}{|c|}{ Funding success } & \multicolumn{2}{|c|}{ Ln(funding amount) } & \multicolumn{2}{|l|}{ NoInvestors } \\
\hline & Coefficient & AME & Coefficient & AME & Coefficient & AME \\
\hline \multicolumn{7}{|l|}{ Entrepreneur-related } \\
\hline Female ratio & $\begin{array}{l}-9.261 * * \\
{[4.431]}\end{array}$ & $\begin{array}{l}-0.900 * * * * \\
{[0.264]}\end{array}$ & $\begin{array}{l}-0.989 \\
{[0.743]}\end{array}$ & $\begin{array}{l}-2.857 * * * * \\
{[0.800]}\end{array}$ & $\begin{array}{l}-0.235 \\
{[0.582]}\end{array}$ & $\begin{array}{l}-389.6^{* *} \\
{[197.8]}\end{array}$ \\
\hline Solo founder & $\begin{array}{l}1.633 \\
{[1.311]}\end{array}$ & $\begin{array}{l}0.0969 \\
{[0.0925]}\end{array}$ & $\begin{array}{l}-0.0502 \\
{[0.266]}\end{array}$ & $\begin{array}{l}-0.0502 \\
{[0.266]}\end{array}$ & $\begin{array}{l}-0.566^{* *} \\
{[0.224]}\end{array}$ & $\begin{array}{l}-167.4 * * \\
{[74.17]}\end{array}$ \\
\hline Risk propensity & $\begin{array}{l}-8.749 * * * \\
{[3.293]}\end{array}$ & $\begin{array}{l}-0.456^{* *} \\
{[0.183]}\end{array}$ & $\begin{array}{l}-1.316 \\
{[0.823]}\end{array}$ & $\begin{array}{l}-1.316 \\
{[0.823]}\end{array}$ & $\begin{array}{l}-0.0242 \\
{[0.603]}\end{array}$ & $\begin{array}{l}-7.804 \\
{[195.2]}\end{array}$ \\
\hline Age_mean & $\begin{array}{l}-0.169 * * \\
{[0.0810]}\end{array}$ & $\begin{array}{l}-0.00879 * * \\
{[0.00430]}\end{array}$ & $\begin{array}{l}-0.0188 \\
{[0.0149]}\end{array}$ & $\begin{array}{l}-0.0188 \\
{[0.0149]}\end{array}$ & $\begin{array}{l}0.00970 \\
{[0.0124]}\end{array}$ & $\begin{array}{l}3.133 \\
{[4.021]}\end{array}$ \\
\hline Education_Dr & $\begin{array}{l}3.101 * * \\
{[1.491]}\end{array}$ & $\begin{array}{l}0.211^{*} \\
{[0.124]}\end{array}$ & $\begin{array}{l}-0.0955 \\
{[0.357]}\end{array}$ & $\begin{array}{l}-0.0955 \\
{[0.357]}\end{array}$ & $\begin{array}{l}-0.265 \\
{[0.227]}\end{array}$ & $\begin{array}{l}-77.13 \\
{[64.58]}\end{array}$ \\
\hline \multicolumn{7}{|l|}{ Campaign-related } \\
\hline Platform big & $\begin{array}{l}3.066 \\
{[2.520]}\end{array}$ & $\begin{array}{l}0.208 \\
{[0.199]}\end{array}$ & $\begin{array}{l}0.444 \\
{[0.352]}\end{array}$ & $\begin{array}{l}0.444 \\
{[0.352]}\end{array}$ & $\begin{array}{l}1.078 * * * * \\
{[0.293]}\end{array}$ & $\begin{array}{l}223.2 * * * * \\
{[60.15]}\end{array}$ \\
\hline Ln(funding threshold) & $\begin{array}{l}2.148 * \\
{[1.191]}\end{array}$ & $\begin{array}{l}0.112 * \\
{[0.0662]}\end{array}$ & $\begin{array}{l}0.770 * * * \\
{[0.273]}\end{array}$ & $\begin{array}{l}0.770 * * * \\
{[0.273]}\end{array}$ & $\begin{array}{l}0.0355 \\
{[0.197]}\end{array}$ & $\begin{array}{l}11.46 \\
{[64.33]}\end{array}$ \\
\hline Seasoned & $\begin{array}{l}0.554 \\
{[1.008]}\end{array}$ & $\begin{array}{l}0.00651 \\
{[0.0516]}\end{array}$ & $\begin{array}{l}0.578 * * * \\
{[0.179]}\end{array}$ & $\begin{array}{l}0.462 * * \\
{[0.180]}\end{array}$ & $\begin{array}{l}-0.0785 \\
{[0.137]}\end{array}$ & $\begin{array}{l}-45.35 \\
{[46.02]}\end{array}$ \\
\hline Female ratio \# seasoned & $\begin{array}{l}-8.004 * * \\
{[3.511]}\end{array}$ & & $\begin{array}{l}-1.868 * * * * \\
{[0.518]}\end{array}$ & & $\begin{array}{l}-0.971 * * \\
{[0.441]}\end{array}$ & \\
\hline Constant & $\begin{array}{l}13.58 \\
{[23.93]}\end{array}$ & & $\begin{array}{l}9.765 * * \\
{[4.681]}\end{array}$ & & $\begin{array}{l}2.891 \\
{[3.562]}\end{array}$ & \\
\hline Ln(alpha) & & & & & $\begin{array}{l}-2.049 * * * * \\
{[0.244]}\end{array}$ & \\
\hline Other campaign-related & Yes & & Yes & & Yes & \\
\hline Promotion-related & Yes & & Yes & & Yes & \\
\hline Venture-related & Yes & & Yes & & Yes & \\
\hline $\mathrm{N}$ & 170 & & 170 & & 170 & \\
\hline LR test $p$-value & 0.0000 & & 0.0000 & & 0.0000 & \\
\hline Adjusted $R^{2}$ & & & 0.742 & & & \\
\hline Pseudo $R^{2}$ & 0.709 & & & & 0.174 & \\
\hline AIC & 132.1 & & 244.871 & & 2085.6 & \\
\hline BIC & 232.5 & & 345.217 & & 2189.0 & \\
\hline
\end{tabular}

This table shows the results from the weighted multiple regression models. Model 13 employs the logit regression method in which the dependent variable is the funding success dummy. Model 14 is based on multiple log-linear regression. The dependent variable is the natural logarithm of the funding amount. Model 15 is negative binomial regression with the number of investors as the dependent variable. Independent variables are defined in Section 3.2. All three models incorporate sampling weights with respect to successful offerings and weights from the propensity score matching model. AMEs refer to average marginal effects of independent variables. Heteroscedasticity-consistent (robust) standard errors are reported in parentheses

$*, * *, * * *, * * * *$ denote significance at the $10 \%, 5 \%, 1 \%$, and $0.1 \%$ levels, respectively 
In(funding threshold). At the 1st percentile of In(funding threshold), the female ratio has a negative effect on the probability of conducting a successful initial offering (significant at the 5\% level). It becomes less relevant at the 10th percentile (significant at the $10 \%$ level). While it does not play a role in explaining the funding success at the 25th and 50th percentiles, it contributes to funding success at higher percentiles of the funding threshold. Overall, these results lend support to Hypothesis 3 that ventures with female managing directors who set higher funding thresholds are more successful in raising capital than male-led ventures.

\subsection{Determinants of funding outcome in seasoned offerings}

In this section, we examine on gender disparities in seasoned offerings. Table 7 presents the results for our regression models based on the weighted matched sample. ${ }^{18}$ We conduct a logit regression in model 13 with the funding success dummy being the dependent variable. Models 14 and 15 investigate factors affecting the funding outcome in terms of the funding amount and number of investors, respectively. We conduct a multiple log-linear regression in model 14 and a negative binomial regression in model $15 .{ }^{19}$ As we are interested in the effect of female ratio on the funding outcome of the treated group (seasoned offerings), we add to all three models the interaction term between female ratio and Seasoned and estimate the average marginal effect of female ratio as well as the other independent variables on the treated group.

The average marginal effect of female ratio is negative and significant in all three models (significant at the $0.1 \%$ level in model 13 and model 14 and at the $5 \%$ level in model 15). This implies that ventures with more female managing directors have a lower likelihood of reaching their target in seasoned offerings, while they also underperform in seasoned offerings in terms of the amount of capital and the number of investors attracted. Therefore, Hypothesis 2 that there

\footnotetext{
18 Robustness tests, including regressions on the unweighted matched sample, are reported in Section A.5 of the online Appendix.

19 There is overdispersion in our post-match weighted data, so negative binomial regressions are preferred over Poisson regressions.
}

is a gender gap in seasoned equity crowdfunding offerings is confirmed. We also find that more risktaking and higher founder age are associated with a lower likelihood to complete a seasoned campaign successfully. In addition, entrepreneurs holding a doctoral degree tend to have a higher likelihood of reaching their target in seasoned offerings, yet the effect of a doctoral degree is weak (significant at the $10 \%$ level). Seasoned campaigns initiated by solo founders attract significantly fewer investors than ventures founded by a team, and pitching seasoned campaigns on large platforms helps them attract more crowd investors, but contributes little to the amount raised or the probability of reaching the target. Further, setting the funding threshold at a higher level increases the amount raised, while its positive effect on the likelihood of funding success is weak (significant at the $10 \%$ level). Overall, all three models are significant at the $1 \%$ level. In particular, model 14 can explain $74.2 \%$ of the variations in the funding amount, while the pseudo $R^{2}$ of model 13 and model 15 are $70.9 \%$ and $17.4 \%$, respectively.

Finally, to investigate whether the gender gap narrows with increasing funding thresholds in seasoned offerings, we extend all three models by adding a three-way interaction term between female ratio, $\ln$ (funding threshold), and Seasoned. ${ }^{20}$ The adjusted $R^{2}$ and the pseudo $R^{2}$ increase, while AIC and BIC decrease, indicating that the models including the interaction term have a larger explanatory power with respect to the funding outcome variables. As the coefficient on the interaction term is positive and significant at the $0.1 \%$ level in all three models, we conclude that discrimination against female entrepreneurs in seasoned equity crowdfunding decreases as the pre-determined funding threshold increases.

Figure 2 shows the estimated average marginal effects of female ratio on the funding outcome at percentiles of $\ln$ (funding threshold). Up to the 10th percentile of $\ln$ (funding threshold), female ratio influences the probability of conducting a successful seasoned offering negatively (significant at the 5\% level). Its effect decreases in size at medium percentiles of In(funding threshold), but is significant at the $1 \%$ level. The average marginal effects are positive at the upper percentiles of $\ln$ (funding threshold) (the 90th to

${ }^{20}$ Detailed results are shown in Table 19 of the online Appendix, Section A.6. 
Fig. 2 Average marginal effects plot for the seasoned offerings. This figure shows the average marginal effects of female ratio across percentiles of $\ln$ (funding threshold) based on the seasoned offering sample. The grey area indicates the $95 \%$ confidence interval

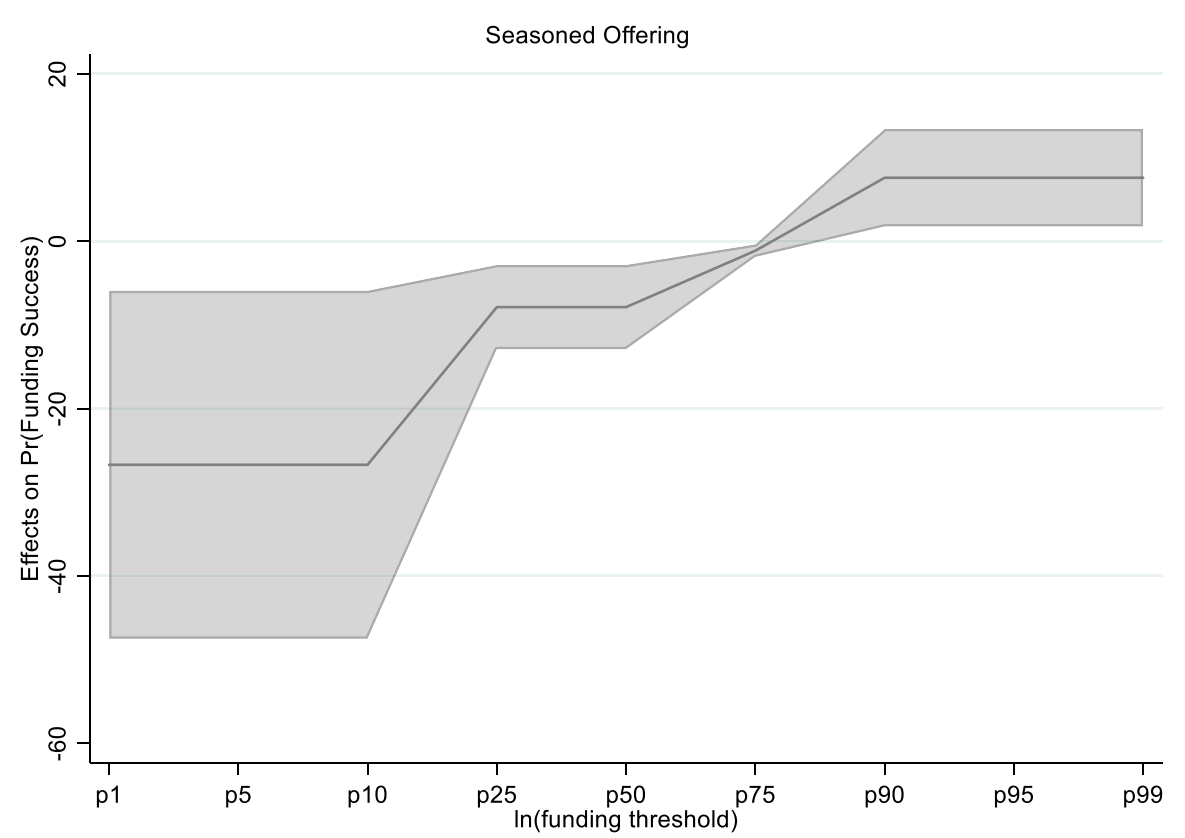

99th percentiles), being statistically significant at the 5\% level. Similar patterns are observed for the other two dimensions of the funding outcome, except that the average marginal effect of female ratio is statistically negligible at the upper percentiles of $\ln$ (funding threshold). Overall, these results confirm Hypothesis 3 with respect to seasoned offerings.

\section{Conclusion}

Based on the hand-collected data on 255 equity crowdfunding campaigns in Germany, we investigated the impact of the founders' gender on their ventures' equity crowdfunding outcomes. Our findings contribute to the growing literature on whether equity crowdfunding democratises entrepreneurial financing by showing that the managing directors' gender does not affect the funding outcome in initial equity crowdfunding campaigns. However, we provided evidence of a gender gap in seasoned offerings in the sense that ventures with female managing directors have a lower likelihood of completing a seasoned campaign successfully and tend to attract less capital as well as fewer crowd investors than ventures solely led by men. Finally, consistent with evidence from the venture capital sector, we showed that the gender gap in seasoned equity crowdfunding offerings narrows for bolder campaign pitches and that female entrepreneurs benefit more than their male counterparts from setting a higher funding threshold. In this respect, our study may be of practical relevance to female entrepreneurs pondering ways to achieve better funding outcomes, as it indicates that they might be able to increase the odds of having their venture funded simply by framing campaign pitches in a more competitive, promotion-focussed way.

The limitations of our study are mainly rooted in the limits to data availability as we had to rely on imperfect proxies for the percentage of unsuccessful projects in order to calibrate our models. However, we mitigated this problem by conducting respective robustness tests using the success rates from rewardbased crowdfunding. Moreover, as our data stems solely from German equity crowdfunding platforms, the generalisability of our results may be limited due to the potential of unobserved effects rooted in country-specific factors.

Overall, our findings are relevant to female entrepreneurs seeking funding from external crowd investors for seed- and early-stage businesses. Moreover, our study may be of interest to policymakers who have an aim to foster female entrepreneurial financing as well as to investors eager to de-bias their investment decision process. 
One possible direction for further research relates to investigating the origins of the gender-related differences in funding outcomes of seasoned offerings. To date, research comparing the post-funding performance of female-led and male-led ventures is still scarce and it is unclear whether the gender gap results from untenable biases or from conscious assessments of the expected venture performance. On the one hand, the funding gap for female entrepreneurs might well be rooted in overt discrimination and/or a set of systemic factors that restrain females' access to vital resources. ${ }^{21}$ On the other hand, the gender gap might result from a disparity in past venture performance originating from differences in male and female entrepreneurs' personal traits and/or experiences. ${ }^{22}$ Hence, a comprehensive comparison of funding success and the performance of funded ventures led by male and female entrepreneurs may further the understanding of the role the founders' gender plays in equity crowdfunding. Finally, our divergent results for initial and seasoned offerings suggest that there might also be systematic differences between the groups of investors typically engaging each type of campaign that may be worth investigating in future research.

Acknowledgements We would like to thank the editor, two anonymous reviewers, Stephanie Birkner, Jerry Coakley, and Ouidad Yousfi for their constructive comments. Further, we are grateful for feedback from participants at the 2018 AFFI conference, the 2018 Infiniti conference, the 2018 Crowdinvesting Symposium, and a research seminar at Waterford Institute of Technology. Furthermore, we would like to thank the German Institute for Economic Research (DIW) Berlin for providing data on entrepreneurs' general risk-taking propensity.

Funding Open Access funding enabled and organized by Projekt DEAL.

Data availability The data analysed in the current study are publicly available at the websites of the crowdfunding platforms indicated in the text.

Code availability The code generated for the current study is available from the authors on reasonable request.

\section{Declarations}

Conflict of interest The authors declare no competing interests.

${ }^{21}$ See Fischer et al. (1993), p. 151; Robb and Watson (2012), p. 546.

22 See Fischer et al. (1993), pp. 152, 157; Orser et al. (2006), p. 650.
Open Access This article is licensed under a Creative Commons Attribution 4.0 International License, which permits use, sharing, adaptation, distribution and reproduction in any medium or format, as long as you give appropriate credit to the original author(s) and the source, provide a link to the Creative Commons licence, and indicate if changes were made. The images or other third party material in this article are included in the article's Creative Commons licence, unless indicated otherwise in a credit line to the material. If material is not included in the article's Creative Commons licence and your intended use is not permitted by statutory regulation or exceeds the permitted use, you will need to obtain permission directly from the copyright holder. To view a copy of this licence, visit http://creativecommons.org/licenses/by/4.0/.

\section{References}

Ahlers, G. K. C., Cumming, D., Günther, C., \& Schweizer, D. (2015). Signaling in equity crowdfunding. Entrepreneurship Theory and Practice, 39(4), 955-980. https://doi.org/ 10.1111/etap. 12157

Alesina, A. F., Lotti, F., \& Mistrulli, P. E. (2013). Do women pay more for credit? Evidence from Italy. Journal of the European Economic Association, 11, 45-66. https://doi. org/10.1111/j.1542-4774.2012.01100.x

Alsos, G. A., \& Ljunggren, E. (2017). The role of gender in entrepreneur-investor relationships: A signaling theory approach. Entrepreneurship Theory and Practice, 41(4), 567-590. https://doi.org/10.1111/etp.12226

Aristei, D., \& Gallo, M. (2016). Does gender matter for firms' access to credit? Evidence from international data. Finance Research Letters, 18, 67-75. https://doi.org/10. 1016/j.frl.2016.04.002

Barasinska, N., \& Schäfer, D. (2014). Is crowdfunding different? Evidence on the relation between gender and funding success from a German peer-to-peer lending platform. German Economic Review, 15(4), 436-452. https://doi. org/10.1111/geer. 12052

Bates, T. (1990). Entrepreneur human capital inputs and small business longevity. The Review of Economics and Statistics, 72(4), 551-559. https://doi.org/10.2307/2109594

Becker-Blease, J. R., \& Sohl, J. (2007). Do women-owned businesses have equal access to angel capital? Journal of Business Venturing, 22, 503-521. https://doi.org/10. 1016/j.jbusvent.2006.06.003

Block, J., Hornuf, L., \& Moritz, A. (2018). Which updates during an equity crowdfunding campaign increase crowd participation? Small Business Economics, 50(1), 3-27. https://doi.org/10.1007/s11187-017-9876-4

Brush, C. G., Carter, N. M., Gatewood, E. J., Greene, P. G., \& Hart, M. (2004). Gatekeepers of Venture Growth: A Diana project report on the role and participation of women in the venture capital industry. Working paper. Retrieved April 24, 2017, from SSRN: https://doi.org/10.2139/ssrn. 1260385

Buttner, E. H., \& Rosen, B. (1988). Bank loan officers' perceptions of the characteristics of men, women, and successful entrepreneurs. Journal of Business Venturing, 3(3), 249258. https://doi.org/10.1016/0883-9026(88)90018-3 
Caliendo, M., \& Kopeinig, S. (2008). Some practical guidance for the implementation of propensity score matching. Journal of Economic Surveys, 22(1), 31-72. https://doi. org/10.1111/j.1467-6419.2007.00527.x

Cholakova, M., \& Clarysse, B. (2015). Does the possibility to make equity investments in crowdfunding projects crowd out reward-based investments? Entrepreneurship Theory and Practice, 39(1), 145-172. https://doi.org/10.1111/ etap.12139

Coakley, J., Lazos, A., \& Liñares-Zegarra, J. M. (2021a). Equity crowdfunding founder teams: Campaign success and venture failure. British Journal of Management. https://doi.org/10.1111/1467-8551.12494

Coakley, J., Lazos, A., \& Liñares-Zegarra, J. M. (2021b). Seasoned equity crowdfunded offerings. Journal of Corporate Finance, 2021, 101880. https://doi.org/10.1016/j. jcorpfin.2020.101880

Coleman, S., \& Robb, A. (2009). A comparison of new firm financing by gender: Evidence from the Kauffman firm survey data. Small Business Economics, 33(4), 397. https://doi.org/10.1007/s11187-009-9205-7

Courtney, C., Dutta, S., \& Li, Y. (2017). Resolving information asymmetry: Signaling, endorsement, and crowdfunding success. Entrepreneurship Theory and Practice, 41(2), 265-290. https://doi.org/10.1111/etap.12267

Crosetto, P., \& Regner, T. (2014). Crowdfunding: Determinants of success and funding dynamics (Working Paper No. 2014-035). Jena Economic Research Papers. Retrieved January 30, 2018, from https://www.econstor.eu/handle/ 10419/108542

Cumming, D. J., Leboeuf, G., \& Schwienbacher, A. (2020). Crowdfunding models: Keep-it-all vs. all-or-nothing. Financial Management, 49(2), 331-360. https://doi.org/ 10.1111/fima.12262

Cumming, D., Meoli, M., \& Vismara, S. (2021). Does equity crowdfunding democratize entrepreneurial finance? Small Business Economics, 56, 533-552. https://doi.org/10. 1007/s11187-019-00188-z

Cummings, M. E., Rawhouser, H., Vismara, S., \& Hamilton, E. L. (2020). An equity crowdfunding research agenda: Evidence from stakeholder participation in the rulemaking process. Small Business Economics, 54(4), 907-932. https://doi.org/10.1007/s11187-018-00134-5

Duarte, J., Siegel, S., \& Young, L. (2012). Trust and credit: The role of appearance in peer-to-peer lending. The Review of Financial Studies, 25(8), 2455-2484. https://doi.org/10. 1093/rfs/hhs071

Eddleston, K. A., Ladge, J. J., Mitteness, C., \& Balachandra, L. (2016). Do you see what i see? Signaling effects of gender and firm characteristics on financing entrepreneurial ventures. Entrepreneurship Theory and Practice, 40(3), 489-514. https://doi.org/10.1111/etap.12117

Eisenhardt, K. M., \& Schoonhoven, C. B. (1990). Organizational growth: Linking founding team, strategy, environment, and growth among U.S. semiconductor ventures, 1978-1988. Administrative Science Quarterly, 35(3), 504529. https://doi.org/10.2307/2393315

Fay, M., \& Williams, L. (1993). Gender bias and the availability of business loans. Journal of Business Venturing, 8(4), 363-376. https://doi.org/10.1016/0883-9026(93)90005-P
Fischer, E. M., Reuber, A. R., \& Dyke, L. S. (1993). A theoretical overview and extension of research on sex, gender, and entrepreneurship. Journal of Business Venturing, 8(2), 151-168. https://doi.org/10.1016/0883-9026(93)90017-Y

Gafni, H., Marom, D., Robb, A., \& Sade, O. (2021). Gender dynamics in crowdfunding (Kickstarter): Evidence on entrepreneurs, backers, and taste-based discrimination. Review of Finance, 25(2), 235-274. https://doi.org/10. 1093/rof/rfaa041

Geiger, M., \& Oranburg, S. C. (2018). Female entrepreneurs and equity crowdfunding in the US: Receiving less when asking for more. Journal of Business Venturing Insights, 10, e00099. https://doi.org/10.1016/j.jbvi.2018.e00099

Greenberg, J., \& Mollick, E. R. (2017). Activist choice homophily and the crowdfunding of female founders. Administrative Science Quarterly, 62(2), 341-374. https://doi.org/ 10.1177/0001839216678847

Greenberg, J., \& Mollick, E. R. (2018). Sole survivors: Solo ventures versus founding teams. Working paper, January 23rd. Retrieved June 28, 2021, from SSRN: https://doi. org/10.2139/ssrn.3107898

Greene, P. G., Brush, C. G., Hart, M. M., \& Saparito, P. (2001). Patterns of venture capital funding: Is gender a factor? Venture Capital, 3(1), 63-83. https://doi.org/10.1080/ 13691060118175

Gupta, V. K., Turban, D. B., Wasti, S. A., \& Sikdar, A. (2009). The role of gender stereotypes in perceptions of entrepreneurs and intentions to become an entrepreneur. Entrepreneurship Theory and Practice, 33(2), 397-417. https:// doi.org/10.1111/j.1540-6520.2009.00296.x

Guzman, J., \& Kacperczyk, A. O. (2019). Gender gap in entrepreneurship. Research Policy, 48(7), 1666-1680. https:// doi.org/10.1016/j.respol.2019.03.012

Haleblian, J., \& Finkelstein, S. (1993). Top management team size, CEO dominance, and firm performance: The moderating roles of environmental turbulence and discretion. Academy of Management Journal, 36(4), 844-863. https://doi.org/10.5465/256761

Hornuf, L., \& Schwienbacher, A. (2018). Internet-based entrepreneurial finance: Lessons from Germany. California Management Review, 60(2), 150-175. https://doi.org/10. 1177/0008125617741126

Hornuf, L., Schmitt, M., \& Stenzhorn, E. (2018). Equity crowdfunding in Germany and the United Kingdom: Follow-up funding and firm failure. Corporate Governance: An International Review, 26(5), 331-354. https://doi.org/ 10.1111/corg. 12260

Hsu, D. H. (2007). Experienced entrepreneurial founders, organizational capital, and venture capital funding. Research Policy, 36(5), 722-741. https://doi.org/10. 1016/j.respol.2007.02.022

Johnson, M. A., Stevenson, R. M., \& Letwin, C. R. (2018). A woman's place is in the... Startup! Crowdfunder judgments, implicit bias, and the stereotype content model. Journal of Business Venturing, 33(6), 813-831. https:// doi.org/10.1016/j.jbusvent.2018.04.003

Kanze, D., Huang, L., Conley, M. A., \& Higgins, E. T. (2018). We ask men to win and women not to lose: Closing the gender gap in startup funding. Academy of Management Journal, 61(2), 586-614. https://doi.org/10.5465/amj. 2016.1215 
Kleinert, S., Volkmann, C., \& Grünhagen, M. (2020). Thirdparty signals in equity crowdfunding: The role of prior financing. Small Business Economics, 54(1), 341-365. https://doi.org/10.1007/s11187-018-0125-2

Kuppuswamy, V., \& Bayus, B. L. (2018). Crowdfunding creative ideas: The dynamics of project backers. In In The Economics of Crowdfunding (pp. 151-182). Palgrave Macmillan. https://doi.org/10.1007/978-3-319-66119-3_8

Latane, B., Williams, K., \& Harkins, S. (1979). Many hands make light the work: The causes and consequences of social loafing. Vol., 37(6), 822-832. https://doi.org/10. 1037/0022-3514.37.6.822

Lechner, C., \& Gudmundsson, S. V. (2014). Entrepreneurial orientation, firm strategy and small firm performance. International Small Business Journal, 32(1), 36-60. https://doi.org/10.1177/0266242612455034

Lee, M., \& Huang, L. (2018). Gender bias, social impact framing, and evaluation of entrepreneurial ventures. Organization Science, 29(1), 1-16. https://doi.org/10.1287/orsc.2017.1172

Ling, Y., Zhao, H., \& Baron, R. A. (2007). Influence of founder-CEOs' personal values on firm performance: Moderating effects of firm age and size. Journal of Management, 33(5), 673-696. https://doi.org/10.1177/01492 06307305564

Long, C. (2002). Patent signals, The University of Chicago Law Review, 625-679. https://doi.org/10.2307/1600501

Mann, R. J., \& Sager, T. W. (2007). Patents, venture capital, and software start-ups. Research Policy, 36(2), 193-208. https://doi.org/10.1016/j.respol.2006.10.002

Marlow, S., \& Patton, D. (2005). All credit to men? Entrepreneurship, finance, and gender. Entrepreneurship Theory and Practice, 29(6), 717-735. https://doi.org/10.1111/j. 1540-6520.2005.00105.x

Mohammadi, A., \& Shafi, K. (2018). Gender differences in the contribution patterns of equity-crowdfunding investors. Small Business Economics, 50(2), 275-287. https://doi. org/10.1007/s11187-016-9825-7

Mollick, E. R. (2013). Swept away by the crowd? Crowdfunding, venture capital, and the selection of entrepreneurs. Working paper, March 25th. Retrieved March 24, 2017, from SSRN: https://doi.org/10.2139/ssrn.2239204

Mollick, E. R. (2014). The dynamics of crowdfunding: An exploratory study. Journal of Business Venturing, 29(1), 1-16. https://doi.org/10.1016/j.jbusvent.2013.06.005

Mollick, E. R., \& Robb, A. (2016). Democratizing innovation and capital access: The role of crowdfunding. California Management Review, 58(2), 72-87. https://doi.org/10. $1525 / \mathrm{cmr} .2016 .58 .2 .72$

Mueller, J. S. (2012). Why individuals in larger teams perform worse. Organizational Behavior and Human Decision Processes: A Journal of Fundamental Research and Theory in Applied Psychology, 117(1), 111-124. https://doi. org/10.1016/j.obhdp.2011.08.004

Nelson, T. (2003). The persistence of founder influence: Management, ownership, and performance effects at initial public offering. Strategic Management Journal, 24(8), 707-724. https://doi.org/10.1002/smj.328

Orser, B. J., Riding, A. L., \& Manley, K. (2006). Women entrepreneurs and financial capital. Entrepreneurship Theory and Practice, 30(5), 643-665. https://doi.org/10.1111/j. 1540-6520.2006.00140.x
Pope, D. G., \& Sydnor, J. R. (2011). What's in a picture?: Evidence of discrimination from Prosper.com. Journal of Human Resources, 46(1), 53-92. https://doi.org/10.3368/ jhr.46.1.53

Ralcheva, A., \& Roosenboom, P. (2016). On the road to success in equity crowdfunding. Working paper, November 1st. Retrieved March 13, 2017, from SSRN: https://doi. org/10.2139/ssrn. 2727742

Ravina, E. (2019). Love \& loans: The effect of beauty and personal characteristics in credit markets. Working paper, February 15th. Retrieved December 15, 2020, from SSRN: https://doi.org/10.2139/ssrn.1107307

Riding, A. L., \& Swift, C. S. (1990). Women business owners and terms of credit: Some empirical findings of the Canadian experience. Journal of Business Venturing, 5(5), 327-340. https://doi.org/10.1016/0883-9026(90)90009-I

Robb, A. M., \& Watson, J. (2012). Gender differences in firm performance: Evidence from new ventures in the United States. Journal of Business Venturing, 27(5), 544-558. https://doi.org/10.1016/j.jbusvent.2011.10.002

Rossi, A., Vanacker, T., \& Vismara, S. (2021). Equity crowdfunding: New evidence from US and UK markets. Review of Corporate Finance, 1, 407-453. https://doi.org/10. 1561/114.00000009

Serfling, M. A. (2014). CEO Age and the riskiness of corporate policies. Journal of Corporate Finance, 25, 251-273. https://doi.org/10.1016/j.jcorpfin.2013.12.013

Signori, A., \& Vismara, S. (2018). Does success bring success? The post-offering lives of equity-crowdfunded firms. Journal of Corporate Finance, 50, 575-591. https://doi. org/10.1016/j.jcorpfin.2017.10.018

Stein, P., Ardic, O. P., \& Hommes, M. (2013). Closing the credit gap for formal and informal micro, small, and medium enterprises. International Finance Corporation Paper No. 94911. Retrieved April 23, 2017, from http:// documents.worldbank.org/curated/en/804871468140039 $172 /$ Closing-the-credit-gap-for-formal-and-informalmicro-small-and-medium-enterprises

Steiner, I. D. (1972). Group process and productivity. Academic Press ISBN: 012665350X.

Tang, Z., Kreiser, P. M., Louis, M., \& Mark, W. K. (2010). Exploring proactiveness as a moderator in the process of perceiving industrial munificence: A field study of SMEs in four countries. Journal of Small Business Management, 48(2), 97-115. https://doi.org/10.1111/j.1540-627X.2010. 00288.x

Thapa, A. (2015). Determinants of microenterprise performance in Nepal. Small Business Economics, 45(3), 581594. https://doi.org/10.1007/s11187-015-9654-0

Vanacker, T., Vismara, S., \& Walthoff-Borm, X. (2019). What happens after a crowdfunding campaign? In In Handbook of Research on Crowdfunding (pp. 227-247). Edward Elgar Publishing. https://doi.org/10.4337/9781788117210. 00015

Vismara, S. (2016a). Equity retention and social network theory in equity crowdfunding. Small Business Economics, 46(4), 579-590. https://doi.org/10.1007/s11187-016-9710-4

Vismara, S. (2016b). Information cascades among investors in equity crowdfunding. Entrepreneurship Theory and Practice, 42(3), 467-497. https://doi.org/10.1111/etap.12261 
Vismara, S., Benaroio, D., \& Carne, F. (2017). Gender in entrepreneurial finance: Matching investors and entrepreneurs in equity crowdfunding. In A. N. Link (Ed.), Gender and Entrepreneurial Activity (pp. 271-288). Edward Elgar Publishing. https://doi.org/10.4337/9781785364747.00015

Younkin, P., \& Kuppuswamy, V. (2018). The colorblind crowd? Founder race and performance in crowdfunding. Management Science, 64(7), 3269-3287. https://doi.org/ $10.1287 / \mathrm{mnsc} .2017 .2774$
Publisher's note Springer Nature remains neutral with regard to jurisdictional claims in published maps and institutional affiliations. 